\title{
Possible Non-Austronesian Lexical Elements in Philippine Negrito Languages*1
}

The languages spoken by Philippine peoples of a Negrito physical type appear to be Austronesian languages of the sort generally found in the Philippines. However, this paper presents a significant body of unique terms gleaned from their vocabularies that may constitute evidence for a non-Austronesian substratum in these languages. Alternative explanations are considered, but the one opted for hypothesizes an early pidgin or trade language, subsequently creolized, that was developed by the Negritos to facilitate communication with in-migrating Austronesians, and later decreolized to such an extent that it came to bear close resemblance to nearby Austronesian languages.

\section{Introduction}

It is a well-known fact that Philippine Negritos speak languages that lexically and syntactically clearly appear to be Austronesian. It is possible without too much difficulty to associate each such language with one of the subgroups of Philippine languages spoken by non-Negritos. For some Negrito language groups, such as the Atta who live in the far north of Cagayan province in Luzon, the relationship with a non-Negrito language appears to be very close. Atta is said to be almost mutually intelligible with Ibanag, the language of the non-Negritos who live in the same region (Reid 1987:44). In other cases, however, such as the Arta of Quirino, the relationship with non-Negrito languages appears to be remote. This language has been characterized as a first-order branch of the Northern Philippine subgroup, with possibly several thousand years of independent development (Reid 1989a:47).

* Originally published as: Possible non-Austronesian lexical elements in Philippine Negrito languages. Oceanic Linguistics 33(1):37-72. (1994)

1 The Social Science Research Institute and the Department of Linguistics, University of Hawai'i. An earlier version of this paper was presented to the Indo-Pacific Prehistory Association Conference in Jogjakarta in 1990. I wish to express my gratitude to the Social Science Research Council and to the Wenner-Gren Foundation for grants that enabled me to conduct research on a number of Negrito languages in 1990. Data from some of that research is included in this paper. I also wish to thank Richard Elkins, Richard Roe, David Zorc, and especially Ronald Himes for commenting on earlier versions of this paper and bringing to my attention cognates from languages with which they are familiar for some of the forms that I thought were restricted to Negrito languages. Derek Bickerton, Robert Blust, Peter Mühlhäusler, Malcolm Ross, and Thomas Headland also provided much helpful comment. I take full responsibility however for the conclusions drawn here, and for the inevitable errors that I am sure are included in the data. 
It is also widely assumed that today's Negritos are the descendants of preAustronesian populations in the Philippines, and that they must have learned to speak Austronesian languages by association with Austronesians when the latter first moved into the Philippines. Such assumptions, however, have not gone unchallenged. Meacham (1991:404-405), for example, suggests that "the predecessors of the Philippine Negritos be counted among the ancient Austronesians.... [They] were speaking Austronesian from its earliest emergence." This is tantamount to claiming that the Philippines was the home of Proto-Austronesian, and that the ancestors of the Negritos were its earlier speakers. Meacham's position is his way of avoiding what he refers to as the conundrum of why Negritos all gave up their original languages in favor of the language of the in-migrating Austronesians. Apart from the problem of explaining what language non-Negritos would have been speaking when they first arrived in the Philippines, Meacham's position simply places the shoe on the other foot: why would the non-Negritos have given up whatever they were speaking to learn the language of the local Negritos?

No linguist has ever seriously proposed the Philippines as a homeland for ProtoAustronesian, for several reasons. If that were the case, one would expect far greater diversity among Philippine languages than actually exists. Although there are a significant number of languages spoken in the archipelago, they are generally considered to be similar with respect to their phonology, morphology, and syntax. But the similarities could be, and probably are, the result of the leveling processes brought about by extensive trade between geographically close language groups. A greater difficulty is explaining away the linguistic evidence that points to Taiwan as the homeland of the Austronesian language family.

In an earlier paper, I posed a question for which I had no answer, "So why did they [i.e., Philippine Negritos] give up their original languages in favor of those of the inmigrating Austronesians?" I suggested then that "perhaps the languages started off as pidgins, and over the thousands of years since then have acquired all the grammatical paraphernalia of Philippine languages" (Reid 1987:57). At that time I thought there was no evidence to support such a hypothesis.

I now believe that it is in principle possible to identify terms in the languages of Negritos that may well be remnants of the languages that were spoken by them in preAustronesian times. If words can be identified in languages spoken by Negritos that are 
not found in languages spoken by non-Negritos, they would constitute evidence for the generally accepted view outlined above that before the arrival of non-Negritos, the Negritos were speaking languages other than Austronesian.

The presence of a possible substratum of non-Austronesian lexical items shared among languages spoken by Negritos suggests that in fact the Negritos did not simply "give up" their original languages, but that there was a process of pidginization, subsequent creolization, and long periods of decreolization that have resulted in the languages as we find them today. It was during the periods of decreolization-gradual adaptation to the forms of the status language-that they acquired the complex morphological and grammatical structures of the languages of their non-Negrito neighbors. The identification of an original Negrito substratum would furthermore be of great value in attempting to identify the possible external relationships of Philippine Negritos. The work of identifying such terms has only just begun (I have concentrated mainly on the Arta and Alta languages), and their comparison with non-Austronesian languages of the Indo-Pacific region is a project that will take an appreciable amount of time and the assistance of scholars familiar with the latter languages.

There are two papers that have discussed the similarities between the physical description and name of the thunder god among some Philippine and Malayan Negritos: Cooper (1941:36) and Blust (1981:302). Both suggest that these similarities are probably best explained as retentions of terms present in a linguistic substratum common to the Austronesian-speaking Negritos of the Philippines and the Austroasiatic-speaking Negritos of the Malay Peninsula.

The identification of a non-Austronesian substratum in the Negrito languages implies that the languages are not themselves truly Austronesian, and therefore have no place in a family tree of those Philippine languages that are genuine descendants of the original Austronesian language to have established itself in the Philippines. I shall continue, however, to refer to them as members of particular subfamilies of Philippine Austronesian languages, with the understanding that this is a convenient fiction for the purpose of identifying those languages with which the Negritos must have acquired the Austronesian component that now overwhelmingly dominates their languages. 


\section{Negrito Languages as Creolized Austronesian}

\subsection{Unique terms in Negrito languages}

In papers I have written on the Northern and Southern Alta languages and on Arta (Reid 1989a, 1991), I have noted that each of these languages has a significant proportion of vocabulary that is unique to each language. Some $17 \%$ of the 539 forms I collected appeared to be unique in Northern Alta, 25\% in Southern Alta, and 29\% in Arta. $^{2}$ The definition that I was using for UNIQUE, "those forms for which no cognate has been found in any other language," allowed the inclusion of words with possible Austronesian etymologies except that they had undergone some innovation, such as either a semantic shift or a sporadic phonological change that is not shared with any other language. If we exclude such possible "Austronesian" words, we are still left with a substantial number of unique words in each language that are phonologically dissimilar and clearly not relatable to words of similar meanings in other Philippine languages.

I had earlier assumed that these unique terms were either Austronesian in origin and had been lost in most if not all other Austronesian languages, or had undergone radical semantic or phonological changes that obscured their relationships, or that they were Negrito coinages subsequent to the switch from the original Negrito languages to Austronesian. Each of these explanations could still be true for certain words (see the discussion in section 2.5), but we must also allow for the possibility that some at least of these words are in fact of pre-Austronesian origin, and thus constitute a Negrito language substratum.

\subsection{Regional Negrito languages}

I am assuming that, prior to Austronesian contact, the Negritos inhabiting distinct geographical areas probably spoke different languages, since there is archaeological evidence that there was human habitation in Luzon for many thousands of years prior

David Zorc (pers. comm.) notes that this is not a specifically Negrito phenomenon. Tagalog has about $12 \%$ unique vocabulary on the Swadesh 200 list; Aklanon has 11\%; Ilongot has as much as $25 \%$. What is important, he notes, is the relatively high percentages (those above $20 \%$ ) for some Negrito language. In fact the high percentage of Ilongot unique forms may be evidence that this language was also formerly a creolized Austronesian language. Although Ilongots do not now identify themselves as Negrito, their physical appearance, and continuing close association with neighboring Negritos, particularly the Alta, suggest the possibility that there has been a greater degree of "admixture" of Austronesian and Negrito languages than is found with other Southern Cordilleran groups. 
to Austronesian in-migration. The languages were probably related to each other, although in some cases only quite distantly. But especially in contiguous geographical areas (for example, along the Eastern Coast of Luzon, or along the Cagayan River and its tributaries), there would probably have been appreciable dialectal differentiation, and also substantial intergroup contact. There is plenty of evidence for such contact going back to the early stages of their adoption of Austronesian languages (see section 2.5). It must be assumed therefore that such contact probably also predated the arrival of the Austronesians. Prior to Austronesian contact then, at least within contiguous geographical regions, the languages spoken by the Negritos probably shared bodies of vocabulary, inherited as well as borrowed. On the other hand, the Negrito languages in other areas of the Philippines (Batak, Palawan; Inati, Panay; and Mamanwa and Ata Manobo, ${ }^{3}$ in Mindanao, for example) must have been much more distantly related, and possibly shared little common vocabulary with their Luzon neighbors.

There is a significant body of comparable data available now for the Negrito languages of Luzon, including over 50 wordlists (see Appendix A). ${ }^{4}$ In order to facilitate the comparison of the data and to identify possible shared unique terms, I have grouped the lists into regions, the inhabitants of which probably spoke at least one distinct language prior to the arrival of the Austronesians.

\subsubsection{North Agta}

This group consists of all the lists that appear to represent communities now speaking a language or languages that are part of what has been called Northern Cordilleran. To date, there has been no systematic analysis done of these lists to determine how many separate languages or dialects they represent, so I have subdivided them on the basis of a casual inspection of their lexical similarities and their geographical locations. $^{5}$

3 Editors' note. Although the name suggests that the Ata Manobo may originally be a Negrito group, they no longer identify themselves as such.

4 The great majority of these lists consist of over 375 lexical items (the list used in Reid 1971), with additional data available for a more limited set, specifically Casiguran Dumagat (Agta) (Headland and Headland 1974), the Arta and Alta languages (Reid 1990), and Umiray Dumaget (Agta) (an unpublished lexicon by Pat McLeod [SIL], and Reid 1990).

5 Headland and Headland, and Headland and Healey (1974), on the basis of lexicostatistical evidence, claim that there are nine "languages and dialects" spoken down the eastern coast of Luzon, from the northern tip almost as far south as Baler. In preparing this paper, it has become apparent that at least one well-defined phonological isogloss divides this group of languages. One set shows an $/ \mathrm{h} /$ 

A. Northern Cagayan (NC), those lists taken in the far north of Cagayan province.
B. Central Cagayan (CC), those lists taken in areas to the west of the Sierra Madre in the central re- gions of Cagayan province.
C. Eastern Cagayan (EC), those lists taken along the Eastern Coast of Cagayan province.
D. Southern Cagayan (SC), those lists taken in the southern regions of Cagayan province.
E. Southern Isabela (SI), one list.
F. Aurora $(\mathrm{AU})$, the data representing the various speech communities speaking what has been called Casiguran Dumagat (Agta).

\subsubsection{Arta (Art)}

Although there are only about 12 remaining speakers of this language (confirmed during my 1990 fieldwork) living in Aglipay, Quirino, it is clearly distinct from all other Negrito languages and is a first order subgroup of Cordilleran ${ }^{6}$ (Reid 1989a). ${ }^{7}$

\subsubsection{Alta}

This group includes several wordlists that can be grouped into two very different languages distantly related to the South-Central Cordilleran languages (Reid 1991).

A. North Alta (NA), primarily spoken in Aurora province.

B. South Alta (SA), sometimes referred to as Kabuluen, primarily spoken in Nueva Ecija and Bulacan.

\subsubsection{Central Agta}

This group of wordlists represents communities scattered over a fairly wide area of Eastern Luzon, from Southern Aurora (Dibut, San Luis), various communities (including Umiray) along the coast in Quezon at least as far as Infanta, Polillo Island, and eastward into Bulacan as far as Norzagaray. The language is generally known as Umiray Dumaget. In Bulacan, the people refer to themselves as Tagabulos. There is some dialectal differentiation, but considering the wide geographical area over which the language is spoken, it is surprisingly homogeneous. This language is said to be spoken by several thousand Negritos, possibly more than any other Philippine Negrito language. No careful analysis has yet been done to place this language unambiguously into the broader context of Philippine subgroups, but a cursory inspection of sound changes

reflex in forms reconstructible with *r. The other set retains $/ \mathrm{r} /$. Much more work needs to be done before the internal relationships of this group can be elucidated.

6 Editors' note. This subgroup of Philippine languages is now renamed as Northern Luzon (see Reid 2007).

7 This number was reduced to 11 with the death of another individual in late 1992. 
and verb morphology suggests that it is probably a Central Philippine languages, related fairly remotely to the Bikol languages. ${ }^{8}$

\subsubsection{South Agta}

There are a number of wordlists of Negrito communities in Southern Luzon that remain unanalyzed. They also appear to be related to the Bikol languages, but the two groups are lexically very different from each other, and from the Central Agta language. No morphological or syntactic data is available for these languages.

A. Camarines Norte (CN). One list available.

B. Camarines Sur (CS). Several wordlists taken in the vicinity of Lake Buhi, each lexically similar to the other and probably representing the same language.

\subsubsection{Sinauna}

There are two wordlists representing dialects of a language spoken in Rizal and contiguous areas of Quezon. Santos (1975) subgroups the language with the Central Luzon subgroup of languages (including Kapampangan and the Sambalic languages).

\subsubsection{Ayta}

There are an appreciable number of lists, some labeled Ayta or Aeta, and some Sambal, each of which is presumably the language of some Negrito community. Wimbish (1986) claims that there are six different Ayta languages spoken in the Zambales mountains: Abelen, Aberlen, Magganchi, Maggindi, Ambala, and Magbeken Ayta. Some of these names can be associated with the lists available to me; others cannot.

\subsection{The identification of a Negrito substratum}

Vocabulary that can be identified as unique to Negrito languages, and that cannot be associated with any Austronesian etymon, allow for several possible interpretations. Either (a) the forms are remnants of one or more of the original Negrito languages, shared either by common inheritance among languages that were more or less closely related genetically, or by borrowing, especially among those Negrito languages that were spoken in geographically contiguous areas; or (b) the forms may be postAustronesian innovations in one of the Negrito languages that have then spread by con-

Editors'note. See Himes (2004) for confirmation of this hypothesis. 
tact into other languages; or (c) the forms may be retentions of an Austronesian etymon that has been lost in all but the Negrito languages.

In a number of instances of the second alternative, such innovations (whether or not they have spread to other groups) can be identified by the phonological structure of the term. For example, in a language in which $/ \mathrm{k} /$ became glottal stop (such as Northern Alta) or was completely lost at some early stage (such as Arta), but in which $/ \mathrm{k}$ / has subsequently redeveloped because of borrowings from languages in which the phoneme was retained, the presence of a unique form containing $/ \mathrm{k} /$ can only be the result of a recent innovation, or is a borrowing from some still unidentified source language. Thus North Alta balík 'small (object)', although unique, is recognizable as possibly a borrowing of North Agta balik (no. 200), with subsequent phonological modification. North Alta piknat 'tear (v.)' is similarly identified as a borrowed item, or as a postAustronesian contact innovation.

How is one able to choose between the alternative interpretations, especially when there is no phonological evidence to force an interpretation? Interpretation (c) is least likely, especially when the form in question is distributed among several Negrito language groups. However, it is clearly not impossible (see section 2.5). To choose between the other interpretations is not so simple.

If the present-day Negrito languages started off as pidgins, we would expect that most areas of the core vocabulary would be from the superstrate language, and that original Negrito vocabulary would persist in highly culture-specific words, such as terms for local flora and fauna that are culturally relevant, and in "secret" vocabulary such as words for sex organs and the like. Similarly, it is probable that such terms that are shared between regional Negrito languages are more likely be retentions than those that are restricted to a single language.

It is necessary then to view any proposed original Negrito term with a certain degree of caution, realizing that the level of confidence associated with each varies considerably, depending at least on whether or not the term is part of the body of culture-specific or secret vocabulary, and the degree to which the term is shared among other Negrito languages. Caution is also in order because, even though proposed original Negrito terms have been carefully checked for similar forms in all other Philippine languages for which data are available, the number of substantial dictionaries is ex- 
tremely limited, and most checking has of necessity been restricted to wordlists and short lexicons.

\subsection{Possible retentions of original Negrito forms}

In the following lists, if a form appears in any of the North Agta, Alta, and/or South Agta regional groups, its actual distribution is indicated following the cited form, with abbreviations for languages within a group separated by commas, and the languages of each regional group separated by semicolons (see section 2.2 for abbreviations, and Appendix A for a list of sources).

${ }^{*} \mathrm{R}$ is the reconstructed protophoneme (probably a voiced velar fricative) having reflexes of $/ \mathrm{g} /$ in the Agta languages and Northern Cordilleran languages, as well as most of the Central and Southern Philippine languages. It is reflected as $/ \mathrm{r} /$ in Ilokano and Arta, as $/ 1 /$ in the South-Central Cordilleran languages and the Alta languages, and as $/ \mathrm{y} /$ in the Batanes languages as well as the Sambalic group ${ }^{9}$. It appears that * $\mathrm{R}$ was not only a phoneme in the language of the Austronesians, but was also present in the languages of the Negritos prior to the arrival of the Austronesians.

All numbered forms are tentative reconstructions. Where there are no comparable data from external languages, a reconstruction has been obtained by using the technique known as internal reconstruction. That is, the forms I propose would have probably predated known phonological changes that have taken place in the languages. These changes include the lowering of schwa and correlated gemination of the following consonant in many of the North Agta languages and Arta; the raising and fronting of the low, central vowel *a following voiced stops, and so on.

A single phoneme in square brackets (examples include nos. 11, 20, 28, and 32) indicates that some languages reflect its presence, others do not. Two phonemes in square brackets indicate an ambiguity in the reconstruction. For example, front vowels (/e/ or /i/) following voiced stops $(/ \mathrm{b} /, / \mathrm{d} /$, and /g/) in North Agta languages may reflect an original *i, or may reflect *a (examples include nos. 10, 12, and 36). Similarly, a glottal stop in North Alta may reflect an original glottal stop, or ${ }^{*} \mathrm{k}$, since ${ }^{*} \mathrm{k}>?$ in this language (examples include nos. 87, 90, and 93). Where there is conflicting evidence for one or more Proto-phonemes in different languages, doublets are proposed

$9 \quad$ Editor's note. This subgroup is now referred to as Central Luzon, with Sambalic being restricted to a set of languages within the subgroup. 
and are usually indicated as separate reconstructions (examples include nos. 19, 30, 42, and 51).

Affixation on most verbal forms (including adjectives) has been removed, since it appears always to be of Austronesian origin, and where affixation has resulted in vowel syncope, a schwa has been replaced in the root, as for example *Rəbi 'plenty, kindness' (no. 6), which is reconstructed from the following data: AGTAu kagbi, Art pagarbian, North Alta ma?albi, South Alta mokkalbi, South Agta (apparently borrowed from South Alta) kalbi 'pity'; ART me?arbi 'kind'.

Affixation on what appear to be morphologically complex, derived nominal forms has been retained, with the affix separated from the reconstructed root by a hyphen and placed in parentheses. For some of these forms, more than one parse is possible. In such cases, alternate analyses are included in the endnotes (see nos. 128 and 131, for example). The data on which the reconstructions are based are given in Appendix B, with an index in Appendix C. To simplify comparison, the phonetic notation of the original sources has been regularized in the following ways: schwa and glottal stop are represented as indicated above, with [ə] and [?]. All word-initial glottal stops have been deleted. Where stress has been indicated, it is marked as an acute accent on the stressed vowel.

I have generally excluded from these lists forms that have a wide distribution in Negrito languages but appear to have a cognate in one of the Northern Philippine languages such as Isnag, Ibanag, or Gaddang, even though it is probable that in such cases the form may originally have been Negrito and has been borrowed into the non-Negrito language. An example is the word for 'night', reconstructed as *kələp, from AGTNC1, AgtNC2, AgtNC3, AgtCC6, AgtEC2, AgtEC3, AgtSC1 kıllıp, AgtCC3 kálap, AgtCC4 k^lıp, AGtEC1 kələp, AGTSC2 kalləp, AGTSC3, AGTSC4 kəlləp, AGTSI kaləp, Au kəláp. In Isnag, there is a corresponding form kallap 'moonless night'.

\subsubsection{Unique forms shared among four Negrito language groups}
1. 'rattan'
*lati
NC, CC, EC, SC; NA, SA ${ }^{10}$

\subsubsection{Unique forms shared among three Negrito language groups North Agta, Alta, and Central Agta}

10 Note also Ayta lawi 'rattan'. 

2. 'rat'
*kuyəy
NC, CC, SC, AU; NA
3. 'ashamed'
*aməs
CC; NA
4. 'vein'
*litid
Au; NA
5. 'bury, inter'
*tapuR
AU; $\mathrm{SA}^{11}$

North Agta, Arta, and Alta
6. 'pity, kindness'
*Rəbi
$\mathrm{AU} ; \mathrm{NA}, \mathrm{SA}^{12}$

Alta, Central Agta, and Sinauna
7. 'snake'
*babak
SA

\subsubsection{Unique forms shared between two Negrito language groups}

North Agta and Arta

$\begin{array}{lll}\text { 8. 'thirst' } & \text { "pələk } & \text { EC, AU } \\ \text { 9. 'hunt' } & \text { "purab } & \text { SC, AU } \\ \text { 10. 'deer, buck' } & \text { *b[ia]dut } & \text { SI, AU } \\ \text { 11. 'fingernail' } & \text { *[1]usip } & \text { EC, } \mathrm{SC}^{13} \\ \text { 12. 'penis' } & \text { "g[ia]ləy } & \mathrm{SI}, \mathrm{AU} \\ \text { 13. 'wall' } & \text { "gəsəd } & \mathrm{SI}^{14} \\ \text { 14. 'dog, puppy' } & \text { *lapul } & \mathrm{AU} \\ \text { 15. 'fire' } & \text { *dukut } & \mathrm{AU} \\ \text { 16. 'hair, feather' } & \text { "pulug } & \mathrm{AU}\end{array}$

\section{North Agta and Alta}

$\begin{array}{lll}\text { 17. 'boil (v.)' } & \text { *ləbut } & \text { NC, CC, EC, SC, SI, AU; NA } \\ \text { 18. 'forget' } & \text { *liksap } & \text { AU; NA } \\ \text { 19. 'summit' } & \text { *taltay/"taytay } & \text { AU; SA }\end{array}$

North Agta and South Agta
20. 'forehead'
*[1]anas
$\mathrm{SC} ; \mathrm{CS}$
21. 'summit'
*kurut
NC, CC, EC, SC; $\mathrm{CS}^{15}$

\section{Arta and Alta}

22. 'fragrant'

*səlub

NA

11 Note also Arta itapug 'bury, inter', borrowed from a language in which * $\mathrm{R}>g$.

12 Note also Ibanag ( $k$ )abbi 'pity'.

13 See Ilongot lukip 'fingernail'.

14 Possibly connected with Proto-Cordilleran *gusud 'fence'.

15 Possibly related to Kalamansig Cotabato Manobo kogol 'ridge'. Possibly also an irregular reflex of $\mathrm{PPH}$ *bakulud 'mountain', Bikol (Iriga) kulud 'mountain', Bikol (Buhi) bakulud 'summit', AGTCS 1 kulud 'summit'. 
Alta and Central Agta

$\begin{array}{lll}\text { 23. 'buttocks' } & \text { *sula } & \mathrm{SA}^{16} \\ \text { 24. 'fast' } & \text { *paripari } & \mathrm{SA} \\ \text { 25. 'know (s.o.) } & \text { *abuyan } & \text { SA } \\ \text { 26. 'leaf' } & \text { *agid } & \text { SA } \\ \text { 27. 'man, male' } & \text { *patud } & \text { SA } \\ \text { 28. 'see' } & \text { *lawi[g] } & \text { SA } \\ \text { 29. 'wall' } & \text { *sagbuy } & \text { SA }\end{array}$

Alta and South Agta

30. 'shoulder'

*sugbuy/*subun(-an) SA; CS ${ }^{17}$

31. 'run'

*kaldit

$\mathrm{SA} ; \mathrm{CN}$

Alta and Ayta

32. 'betel leaf'

$*$ li[t]lit

SA

Central Agta and Sinauna

33. 'waterfall'

*gərəy

\subsubsection{Unique forms shared between North and South Alta}

$\begin{array}{lll}\text { 34. 'accompany' } & \text { *ilan } & \text { NA, SA } \\ \text { 35. 'know' } & \text { *ənul } & \text { NA, SA } \\ \text { 36. 'lazy' } & \text { *b[ia]kət } & \text { NA, SA } \\ \text { 37. 'pregnant' } & \text { *tuyud } & \text { NA, SA } \\ \text { 38. 'sleep' } & \text { *puləd } & \text { NA, SA }\end{array}$

\subsubsection{Unique forms shared among North Agta languages}

$\begin{array}{lll}\text { 39. 'heavy' } & \text { *dəgi } & \text { NC, CC, EC, SC, Au }{ }^{18} \\ \text { 40. 'thick' } & \text { *bagəl } & \text { NC, CC, EC, SC, AU } \\ \text { 41. 'bitter' } & \text { *təkak } & \text { NC, CC, EC, SC } \\ \text { 42. 'butterfly' } & \text { *lullu/*lilli } & \text { NC, CC, EC, SC }{ }^{19} \\ \text { 43. 'dry in sun' } & \text { *sarun } & \text { NC, CC, EC, SC } \\ \text { 44. 'hear' } & \text { *tima[n, y] } & \text { NC, CC, EC, SC } \\ \text { 45. 'hunt' } & \text { *lagum } & \text { NC, CC, EC, SC } \\ \text { 46. 'mountain' } & \text { *amugud } & \text { NC, CC, EC, SC } \\ \text { 47. 'old (obj.)' } & \text { *ligid } & \text { NC, CC, EC, SC } \\ \text { 48. 'sun' } & \text { *pamalak } & \text { NC, CC, EC, SC }\end{array}$

16 Possibly an irregular reflex of $\mathrm{PPH}$ *súlat: Bontok súlat 'to block a hole', Bikol sulat, Ilokano sullat 'cork, stopper', Hanunóo súlat 'hole, such as body openings', súlat bulí? 'anus', Alangan súlat 'anus'.

17 Editors' note. Jason Lobel (pers. comm.) notes that sugbong 'shoulder' is also found in Waray.

18 But note Northern Kankanay dəg?ay 'strain, strive, make an effort, exert one's self'.

19 Various forms in Kalinga dialects, all meaning 'dragonfly', are possibly connected, as for example Balenciagao balliliy, Lubuagan belliliy, Puapo bililiy, Kolayo ballili. 


$\begin{array}{lll}\text { 49. 'termite' } & \text { *sarik } & \text { NC, CC, EC, SC } \\ \text { 50. 'throw (away)' } & \text { *tugbak } & \text { NC, CC, EC, SC }{ }^{20} \\ \text { 51. 'fingernail' } & * \text { "lu/*[1]udis } & \text { NC, CC, EC } \\ \text { 52. 'run' } & \text { *buyut } & \text { NC, CC, EC } \\ \text { 53. 'wing' } & * \text { kəpig } & \text { NC, EC, SC } \\ \text { 54. 'throw' } & * \text { b[ia]sag } & \text { CC, EC, SC } \\ \text { 55. 'waterfall' } & \text { *sənad } & \text { EC, SC, SI } \\ \text { 56. 'shoulder' } & \text { *dapi } & \text { NC, EC } \\ \text { 57. 'call' } & \text { *dulaw } & \text { SC, AU } \\ \text { 58. 'sweat' } & \text { *asub } & \text { SI, AU }{ }^{21}\end{array}$

\subsubsection{Unique forms restricted to a single Negrito language}

\section{North Agta}

59. 'butterfly'

60. 'sit'

61. 'thirst'

62. 'urine'

63. 'walk'

64. 'hear'

65. 'rattan'

66. 'run'

67. 'salt'

$\begin{array}{ll}* \text { *lumlum/*limlim } & \text { CC } \\ \text { *tugkuk } & \text { CC } \\ * \text { g[ia]mtan } & \text { CC } \\ \text { "sitəb } & \text { CC } \\ \text { *sugut } & \text { CC } \\ \text { "sanig } & \text { SC } \\ \text { *karat } & \text { SC } \\ \text { *gutuk } & \text { SC } \\ \text { *b[ia]gəl } & \text { SC }\end{array}$

Arta

\begin{tabular}{|c|c|}
\hline 68. 'afternoon' & (ma-)*lutəp \\
\hline 69. 'arrive' & $* \operatorname{digdig}^{22}$ \\
\hline 70. 'bone' & *sagnit \\
\hline 71. 'butterfly' & *pippun \\
\hline 72. 'drink' & *tim \\
\hline 73. 'ear’ & $*$ ibəy $^{23}$ \\
\hline 74. 'lime' & *yusu \\
\hline 75. 'man, male' & ${ }^{*}$ gilan $(-a n)^{24}$ \\
\hline 76. 'mosquito' & *buyur \\
\hline 77. 'old (man)' & *dupu \\
\hline 78. 'one' & *sipay \\
\hline 79. 'rain' & *punəd \\
\hline 80. 'run' & *gurugud \\
\hline
\end{tabular}

20 Note also Ibanag tabbo? 'throw away', Pangasinan and SB13 (Sambal) tupak 'throw', and Matigsalug Manobo dogpak 'throw away'.

21 Note Ifugao (Kiangan) oháb ( < *əsáb 'warmth inside a house; person who has fever').

22 Note also Naga Bikol digdi 'come'.

23 Note North Alta tibay 'hear'.

24 Note Arta gilay 'penis'. 

81. 'say, tell'
*bud
82. 'sleep'
*idəm
83. 'two'
*təlip

\section{North Alta}

$\begin{array}{ll}\text { 84. 'burn' } & \text { *təmuk } \\ \text { 85. 'call' } & \text { *yuk } \\ \text { 86. 'collapse' } & \text { *bəwəl }{ }^{25} \\ \text { 87. 'depart' } & \text { *əg[?k]ay } \\ \text { 88. 'fruit' } & \text { *ian } \\ \text { 89. 'hear' } & \text { *tibəy } \\ \text { 90. 'hit, strike' } & \text { *pu[?k]na } \\ \text { 91. 'lie down' } & \text { *ədsay } \\ \text { 92. 'locust' } & \text { *pəsal } \\ \text { 93. 'long' } & \text { *lə[?k]aw } \\ \text { 94. 'penis' } & \text { *gəyət } \\ \text { 95. 'put, place' } & \text { *dətun } \\ \text { 96. 'red' } & \text { *silit } \\ \text { 97. 'seek' } & \text { *alyuk } \\ \text { 98. 'stand' } & \text { *payun } \\ \text { 99. 'wait' } & \text { *tanud }\end{array}$

\section{South Alta}

100. 'ant'

*il[วu]m

101. 'black'

*lit[əu]b

102. 'blow (v.)'

*uswa

103. 'burn'

*tiduk

104. 'bury, inter'

*laba

105. 'butterfly'

(ma-)*lawak

106. 'buttocks'

*timuy

107. 'call'

*gawi

108. 'carabao'

*udun(-an)

109. 'cry'

*kəbi

110. 'deep'

*tanaw

111. 'fall (v.)'

*pagpag

112. 'fight/quarrel'

*itaw

113. 'fingernail'

*lunu

114. 'loincloth'

*g[ia]nat

115. 'long (time)'

*təwali

116. 'other (diff.)'

*kalad

117. 'put, place'

*bənu

25 Note also Proto-Kalahan *b[əu]wəl 'rotten'. 


$\begin{array}{lll}\text { 118. } & \text { 'rain' } & \text { *dəsu } \\ \text { 119. } & \text { 'sit' } & \text { *layad } \\ \text { 120. } & \text { 'stand' } & \text { *piad } \\ \text { 121. } & \text { 'tail' } & \text { *lambuy } \\ \text { 122. } & \text { 'three' } & \text { *sayay } \\ \text { 123. } & \text { 'tree, wood' } & \text { *lab[ia]t } \\ \text { 124. } & \text { 'true' } & \text { *kuduR } \\ \text { 125. } & \text { 'vagina' } & (\mathrm{i}-)^{*} \text { play } \\ \text { 126. } & \text { 'widow, widower' } & \text { (na-)*dit } \\ \text { 127. } & \text { 'wind' } & \text { *kabu(-an) }\end{array}$

\section{Central Agta}

128. 'bone'

*kaks(-an) ${ }^{27}$

129. 'call'

*ulay

130. 'climb'

*dawit

131. 'crocodile'

$(\mathrm{man}-)^{*} \mathrm{atu}^{28}$

132. 'feather'

"putput ${ }^{29}$

133. 'hair'

*sapuk

134. 'hunt'

*ikag

135. 'ladle'

*lukuy ${ }^{30}$

136. 'long (time)'

*luy ${ }^{31}$

137. 'no, not'

*eyen

138. 'pound'

*buntul

139. 'rain'

*tapuk

140. 'run'

*g[ia]kan

141. 'sand'

*layas

142. 'sit'

*lipa

143. 'sleep'

*pida ${ }^{32}$

144. 'stand'

*[uə]di

145. 'sweat'

*aldut/*ald[ia]t

146. 'vagina'

*kin(-an)

147. 'water, river'

*urat

148. 'white'

*lapsay

26 There is an apparently corresponding form in Arta kurug 'true', but the presence of $/ \mathrm{k}$ / indicates that it is borrowed, probably from a North Agta language. This then suggests a reconstruction with a final *R, probably *kuduR 'true'. Bontok has kutug 'lie'.

27 Or (ka-)*ksan.

28 Or (ma-)*yatu.

29 But note PMP *putput 'pluck, pull out'.

30 Made of coconut shell.

31 On the basis of this form with Casiguran Dumagat ale, Himes reconstructs Proto-Northern Philippines *?alay 'long time'.

32 Compare also South Agta piges ( < * pigas) 'sleep'. 
South Agta

\begin{tabular}{|c|c|c|}
\hline 149 & 'fire' & *adin \\
\hline 150 & 'mosquito' & *kubuy \\
\hline 51 & 'shoulder' & *mugmug(-an) \\
\hline 152 & 'sleep' & *lubat \\
\hline
\end{tabular}

Sinauna

$\begin{array}{lll}\text { 153. 'child' } & \text { *ubun } \\ \text { 154. 'leaf' } & \text { *hayin }{ }^{34} \\ \text { 155. 'sit' } & \text { *səna } \\ \text { 156. 'stone' } & \text { *igay } \\ \text { 157. 'wind' } & \text { *rugus }\end{array}$

Ayta

158. 'see' *ələw

\subsection{Other evidence for a Pidgin origin of Negrito languages}

As indicated above, I had earlier assumed that apparently unique terms in Negrito languages, if not post-Austronesian coinages, were probably Austronesian in origin and had been lost in most if not all other Austronesian languages, or had undergone radical semantic or phonological changes that obscured their relationships. There are a number of such terms, which I will discuss in this section. I shall claim, however, that they constitute further possible evidence for the presence of a pidgin in early contact times.

The discussion will focus on two areas: forms with unusual distribution of lookalikes in Austronesian languages, and possible Austronesian forms that have undergone radical phonological and/or semantic change. ${ }^{35}$

\subsubsection{Unusual distribution of Austronesian look-alikes in Negrito languages}

The distribution of these forms is unusual, in that if they are really of Austronesian origin, they have been lost in most, if not all, of the non-Negrito languages of Luzon, and in some cases are retained only in a few languages in Mindanao (such as the Negrito language Mamanwa), and/or Palawan (including Batak). How can we account for this fact? One possible explanation is that they were learned by the Negritos as part of

33 Editors' note. Jason Lobel (pers. comm..) notes that the term kubung means 'mosquito net' not 'mosquito' in Rinconada Agta as well as in Bikol.

34 Possibly cognate with Tagalog hayin 'to set the table'.

35 The use of the term 'look-alike' rather than 'cognate' leaves open for the present the question of whether or not true cognation is involved. 
the Austronesian component of a pidgin during early contact with the Austronesians as they moved into Luzon from the north. Subsequently this contact language spread and was used fairly widely by different Negrito groups in Luzon in communicating with their Austronesian neighbors. During this stage the contact language acquired lexical items from the particular Negrito group that used it, and later these regional dialects shared in the phonological and grammatical innovations that developed in the languages of the local Austronesian group with which it was associated. With the dispersal of the Austronesian languages southward through the Philippines, the pidgin, by now creolized, maintained many of the old forms, even though they had become obsolete in the Austronesian languages from which they had originally come.

Another possible explanation is that those forms that only occur in Negrito languages in Luzon and non-Negrito languages in Mindanao may be part of a Negrito substratum in the non-Negrito languages of the Central and Southern Philippines. A number of the Manobo-language-speaking groups in Mindanao, including the Ata, Tigwa, and Matigsalug, although not hunter-gatherers, nor identifying themselves as Negrito, have a significant proportion of their population with clearly negroid genes (Richard Elkin, pers. comm.). Earlier Negrito populations in these areas have apparently been assimilated into the Manobo population, and many have left a substratum in the Manobo language of the area where they originally lived.

Some of the phonological changes (such as the raising and fronting of $/ \mathrm{a} / \mathrm{after} / \mathrm{b} /$, $/ \mathrm{d} /$, and $/ \mathrm{g} /$, and the lowering of high front and back vowels-that is, $/ \mathrm{i} / \mathrm{and} / \mathrm{u} / \mathrm{be}-$ coming /e/ and /o/ respectively-in some environments) that are found throughout the Negrito languages of eastern Luzon may also have had their source in this early contact language. It could be merely coincidence that the North Agta language spoken in the Casiguran area of Aurora has a more complex vowel system than any other Philippine language (Headland and Wolfenden 1967, Reid 1973, Headland and Healey 1974), or it may be substratal influence from the North Agta language originally spoken in this area.

Another common phonological change found in these languages was the loss of certain word-medial consonants, and subsequent reduction of the vowel sequence, resulting in a number of monosyllabic morphemes, as for example North Agta god < *Rawəd 'betel leaf', pet < *paqit 'bitter', buk < *buhuk 'hair', beg < *bahaR 'g-string', don $<$ *dahun 'leaf'. It seems possible that the Negrito languages prior to Austronesian- 
contact were far more tolerant of monosyllabic morphemes than Austronesian languages typically are. A number of such morphemes appear in the preceding and following lists, as for example *bud 'say, tell', *but 'throw', *əl 'all', *lu 'fingernail', *luy 'long time', *pis 'all', *tim 'drink', and *tug 'coconut shell ladle'. Other abbreviated forms that are clearly of Austronesian provenance occur widely. Note, for example, Central Agta $b u$ 'seed of fruit' (see Proto-Philippine [PPH] *buaq, *buna); $p a$ 'thigh' (see PPH *paqa); $a b a$ 'shoulder' (see PPH *abaRa); bol 'hold' (see Proto-North Cordilleran *əbəl). Similar abbreviated forms that are the result of syncopated intervocalic consonants also occur in some of the non-Negrito languages of Cagayan, such as Ibanag and Gaddang, so these may be areal features having nothing at all to do with the morphological structure of the original Negrito languages.

\subsubsection{Forms shared among four Negrito language groups in Luzon}

North Agta, Alta, Central Agta, and Sinauna

159. 'abaca'

*arutay

Au; NA

Reflexes of Proto-Southern Philippines *qaRútay 'wild banana' are found in Aklanun agugútay, Cebuano, Hanunóo agútay, and Tboli kelutay. It is not known to occur in any of the (non-Negrito) languages of Luzon.

North Agta, Alta, Central Agta, and South Agta

160. 'chin, jaw' *səla $\quad$ NC, CC, EC; NA, SA

Related forms occur in a number of Southern Philippine languages, including Tagalog síhang, and Bikol sálang. It is not known to occur in any of the (non-Negrito) Cordilleran languages of Luzon.

North Agta, Arta, Alta, and Central Agta

161. 'throw away' *but AU; NA, SA

This form is not known to occur in the non-Negrito languages of Luzon. A possibly related form occurs in the Southern Mindanao languages: Blaan bat, Tboli bot 'throw away', and is probably relatable ultimately to PPH *i-batu 'throw'. Note also: AGTSI ibatol, Ibanag ivuttu, AGTCC5 ibuttuy 'throw'.

\subsubsection{Forms shared among three Negrito language groups in Luzon} North Agta, Alta, and Ayta

162. sit *iknud NC, CC, EC, SC, SI, AU; NA ${ }^{36}$

36 Sambal Ayta ikno? 'sit'. 
This is not known to occur in the non-Negrito languages of Luzon. Probable related forms occur in Kalagan, Mansaka, Dibabawon Manobo, and Subanun ijkud 'sit'.

\section{North Agta, Alta, and Central Agta}

$$
\text { 163. wing *olad NC, CC, SC; } \mathrm{SA}^{37}
$$

This is not known to occur in the non-Negrito languages of Luzon. It is shared also in Palawan by Batak and Aborlan Tagbanwa; in Mindanao by Western Bukidnon Manobo; and occurs in a number of nonPhilippine Austronesian languages.

$$
\text { 164. red *dadag CC, EC, SC, Au; SA }
$$

This is not known to occur in the non-Negrito languages of Luzon. Related forms are found in Buhid of Mindoro, Aborlan Tagbanwa in Palawan, and Mamanwa. The form is reconstructed for Greater Central Philippines by Zorc as *dadag 'red'.

$$
\text { 165. 'deep, under' *salad AU; NA, SA }
$$

This is not known to occur in the non-Negrito languages of Luzon. Related forms occur in ProtoMansakan *salad 'space under a house', and Dibabawon Manobo patisalad 'downward'.

North Agta, Arta, and Alta

$$
\text { 166. 'fly (v.)' *əbər/ *igbər NC, CC, EC, SC, SI, AU; NA, SA }
$$

This is not known to occur in the non-Negrito languages of Luzon. Tiruray (a South Mindanao language) ibər 'throw away' is possibly related, and see also ART $i$-bar 'throw'.

$$
\text { 167. 'run' *ginan SI, AU; } \mathrm{NA}^{38}
$$

Note also ART ginan 'depart'. This is not known to occur in the non-Negrito languages of Luzon. See Sibale (Bisayan) ginan 'go (away), leave'.

\subsubsection{Forms shared between two Negrito language groups}

\section{North Agta and Arta}

$$
\text { 168. 'back' *səpay NC, CC, EC, SC, AU }
$$

This is not known to occur in the non-Negrito languages of Luzon and is possibly related to Tiruray sagan 'back'.

\section{Alta and Central Agta}

$$
\text { 169. 'cheek, face' (pa-)*sinil NA, SA }
$$

37 Also occurs meaning 'feather' in some North Agta languages (NC, CC, EC, SC). This form is a reflex of PMP *qelaj 'wing, feather, thin object' (reconstructed by Dempwolff, revised by Charles).

38 Compare Central Agta gikan 'run'. 
See Aborlan Tagbanwa basinil 'cheek'. Several Northern Agta groups, as well as Gaddang, have reflexes of *padinil 'cheek'.

\section{Alta and Sinauna}

170. 'water, river' *la?u

SA

This is not known to occur in the non-Negrito languages of Luzon and is possibly related to ProtoManobo *la?u 'thirsty', with cognates in Sangir and Sangil. See also PPH *láud 'high seas'.

\subsubsection{Forms restricted to a single Negrito language}

\section{North Agta}
171. 'skinny'
*rasa
NC, CC, EC, SC, SI

This is not known to occur in the non-Negrito languages of Luzon. Related forms from PPH "Rasa? 'skinny' occur in a number of Southern Philippine languages, as reflexes of *Raseq (Charles 1973).
172. 'chicken'
*kati
SI

This is probably cognate with Proto-Meso-Philippine *kati? 'rooster used as a decoy in a wild chicken snare'.

\section{South Agta}

173. 'rain' *g[ia]mis $\quad \mathrm{CN}$

This is not known to occur in the non-Negrito languages of Luzon. Compare Tasaday damas 'rain'.

North Alta

174. 'all' *ol(-an)

This is not known to occur in the non-Negrito languages of Luzon. An apparent cognate occurs in Binukid Manobo alan 'all'.

\subsubsection{Austronesian look-alikes in Negrito languages that often show radical spo- radic phonological and/or semantic changes}

It is surprising the number of forms that maintain only a single-syllable (usually, but not always, first syllable) similarity to possibly corresponding Austronesian forms. ${ }^{39}$ Excluded from this set of data are forms with first-syllable similarity to an Austronesian form, but in which there is a recognizable regularity in the second-syllable modification, as in North Alta terms with second syllables originally beginning with a voiced

39 This phenomenon has been extensively studied in Blust 1988. 
stop plus /a/ sequence, in which /d/ is inserted before the second vowel, which is itself reflected as schwa. For example:

$\begin{array}{lll}\text { 'body' } & \text { abdə? } & <* \text { abak } \\ \text { 'eel' } & \text { igdat } & <* \text { igat } \\ \text { 'fat' } & \text { tabda } & <* \text { taba } \\ \text { 'light weight' } & \text { lagdən } & <* \text { laga?an } \\ \text { 'root' } & \text { ugdat } & <* \text { ugat } \\ \text { 'woman' } & \text { dəbdi }{ }^{40} & <* \text { baba?i }\end{array}$

Words that have been radically changed phonologically or that have shifted semantically, and that would therefore have been a barrier to communication, can hardly be used to substantiate the presence of a pidgin, the very purpose of which is to facilitate communication between groups that have no common language. However, it is possible that after creolization and the loss of the original Negrito languages, such forms developed as part of a secret language and ultimately became linguistic markers of group identity.

\subsubsection{Forms shared among three Negrito language groups}

North Agta, Arta, and Alta

$\begin{array}{lll}\text { 175. 'cut, slice' } & \text { *galgəl } & \text { NC, CC, EC, SC, SI, AU; NA } \\ \text { 176. 'near' } & \text { *b[ia]kən } & \text { NC, CC, EC, SC; NA }\end{array}$

See Ibanag biko 'near'.

See PCORD *gə[d]gəd; PPH *gələt 'cut, slice'.

177. 'bathe' *dimuy SI; SA

See PPH *diRus 'bathe'; Ilongot (Kakiduge:n) diyuy 'wash body'.

North Agta, Alta, and Central Agta

178. 'say, tell; choose' *pa?ita NC, CC, EC, SC; SA

This form is obviously a reflex of $\mathrm{PPH}$ *pakita 'show'. The semantic shift is restricted to the Negrito languages indicated, and is not found in non-Negrito languages.

\subsubsection{Forms shared between two Negrito language groups}

North Agta and Arta

179. 'monkey'

*burug NC, CC, EC, SC, SI, AU

40 The initial /d/ in this form is apparently a result of dissimilation, occurring also in North Alta dəbuy $<$ *babuy 'pig'. 
See Proto-Cordilleran *buRayan 'monkey'. Yogad burog 'monkey' is possibly a borrowing from a Negrito language.

180. 'crocodile' *bukarut NC, CC, EC, SC, AU

See PPH *buqaya 'crocodile', ${ }^{41}$ Kalamianan bukaya?, Batak buyut 'crocodile', Ilokano bokkarut 'kind of crocodile with variegated skin'.
181. 'short (obj.)'
*pirit
SC, SI, AU

See Proto-Cordilleran *pitik 'short'.
182. 'face'
*mud[ia]t
SI

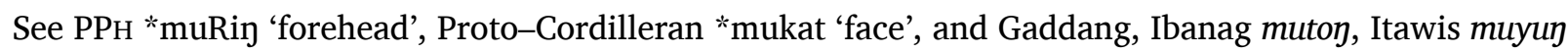
'face', and so forth.
183. 'heavy'
*dətun
SI

See Proto-Northern Cordilleran *dəgi, $\mathrm{PPH}$ *daRmət, and Ilokano dagsen 'heavy'.

\section{North Agta and Alta}

184. 'forehead' *k[iə]dəp NC, EC, AU; NA, SA

See PPH *kiday and Proto-South-Central Cordilleran *kituy 'forehead'.

185. 'drunk, dizzy' *linug AU; NA, SA

This may be related to Proto-Cordilleran *liwey ‘dizzy'.

186. 'person, non-Neg.' *uRdin NC, CC, EC, SI; NA

An apparent set of cognates meaning 'red' occurs only in Atta ujjo:jin, and its closely related neighboring language Ibanag uzzin. The meaning 'non-Negrito person' occurs only in Negrito languages.

187. 'hard (substance)' *kətug AU; NA

See Balangao kənəg, Kankanay kəntəg, Tigwa Manobo kəgal, and Sangir and Sangil kəti? 'hard'. A possible cognate occurs in Isnag kattug 'lust, sexual desire', makattug 'to suffer an erection'.

\section{Arta and Alta}

188. 'water, river' *wagət NA, SA

See PPH *waqiR 'water, stream'.

189. 'cry' *siak NA

41 If these forms are in fact related, the $/ \mathrm{k} /$ reflex of $\mathrm{PPH}{ }^{*} \mathrm{q}$ in the Negrito forms places the time of original contact at a very early period in the development of Philippine Austronesian languages, since * $\mathrm{q}$ is only retained as $/ \mathrm{k} /$ elsewhere in the Philippines in Kalamianan, and Tboli in the south of Mindanao. Other Negrito forms that show /k/ as a possible reflex of * $\mathrm{q}$ are nos. 189 and 208. 
See Tagalog iyak and Kapampangan kiyak 'cry'. However, this may be relatable to Proto-Western Malayo-Polynesian *Siaq 'shy, ashamed'.

190. 'earth, soil' *tapək NA

See $\mathrm{PPH}$ *tanəq 'earth, soil'.

Alta and Central Agta

191. 'mud' *lutit NA, SA

See $\mathrm{PPH}$ *lusak; Proto-Bashiic *lutək; Isnag lupay; Proto-Cordilleran *luyek; Batak lubut; Kala-mianan lunay, lugmuk 'mud'.

192. 'sweet' *lanis NA, SA

See Bontok lamsit; Ilokano lami?is 'sweet'.

193. 'carry, bring' *[aə]da ${ }^{42} \quad$ NA

See Tagalog dala 'bring'; Ilongot (Kawayan, Dupax) 2ədəm, (Payo) ?adə ‘bring, carry'.

194. 'big' *hana SA

See PPH *ma-Raya 'big'. Perhaps this was borrowed from a North Agta language in which *R $>r>h$.

195. 'old (woman)' *gupad SA

See Tagalog magulay ‘old person'.

196. 'waterfall' *tabi SA

See Kapampangan and Sinauna talon 'waterfall'.

197. 'woman, girl' (ma-)*huna SA

See Tagalog huna? 'frailty, fragility of structure', borrowed into AGTAU as huna 'weak'.

\subsubsection{Forms shared between North and South Alta}

198. 'love'

*bud[ia]

NA, SA

See AgtUm bu?ot, Bisayan bu?út 'love'

199. 'hot, fever'

*pənay

NA, SA

See Inibaloi patay 'hot'. The Alta languages and Inibaloi are all part of the Meso-Cordilleran sub-group of Philippine languges.

42 Several other Austronesian reduplicated forms of the shape $C_{1} V_{1} \cdot C_{1} V_{1}\left(C_{2}\right)$ occur in Negrito languages with the shape $2 \mathrm{CV}$, as for example PPH *nana, AltN2, N3 ana 'pus' and PPH *mamaq, Sin1 ama?, AGTAu əma 'betel nut chew'. 


\subsubsection{Forms shared among North Agta languages}

200. 'small (obj.)'

See Proto-Malayo-Polynesian *kədik

201. 'star'

*balik

NC, CC, EC, SC, SI

'small' (but no other known reflexes in the Philippines).

*pu[st]ian NC, CC, EC, SC

Although none of the languages has a $t$ reflex in this form, it may be a reflex of PPH *putiq 'white', borrowed from a language such as Ibanag, in which *t became $s$ before a high-front vowel.
202. 'tail'
*bunid ${ }^{43}$
$\mathrm{NC}, \mathrm{CC}<\mathrm{EC}, \mathrm{SC}$

See Tagalog, South Agta (CN) buytot 'tail'.

203. 'white' *pun[st]it NC, CC, EC, SC

See PPH *putiq 'white'.

204. 'mud' *ludəg CC, EC, SC

See PPH *lusak; Proto-Bashiic *lutək; Isneg lupay; Proto-Cordilleran *luyek; Batak lubut; Kala-mianan lunay, lugmuk 'mud'.

205. 'sky' *lakup NC, EC

See PPH *layit 'sky'.

\subsubsection{Forms restricted to a single Negrito language}

\section{North Agta}

206. 'mud' *lukit NC

See PPH *lusak; Proto-Bashiic *lutək (see no. 204).

207. 'ladle (coconut shell)' *tug SI

See PPH *saduk 'coconut shell ladle'.

208. 'rat' *bukət ${ }^{44}$ SI

See Proto-Nuclear Cordilleran *buwət 'a kind of large native rodent'. This implies a PPH *buqət. Ifugao and Yogad bukat 'rat' are also possibly related.

Arta

209. 'bad' *balanu

43 In NC and EC also 'feather'.

44 See also Arta bukát 'rat' (the presence of a medial $k$, suggests that the form is a borrowing from North Agta), and AgTAu bukat 'mouse'. 
This may be related to $\mathrm{PPH}$ *balanaw 'rainbow'. (The appearance of a rainbow in many Philip-pine cultures is considered to be a bad omen.)

$$
\text { 210. 'night' *baywət }
$$

See Kapampangan beji and South Agta báni 'night'; also Bikol baygi 'night' and Ilongot (Payo) bəygi 'midnight'.

$$
\text { 211. 'vagina' *sabit }
$$

See Bontok sipit and Balangao sopet 'vagina'.

\section{Alta}
212.
'big'
*damanta
SA

See Proto-Cordilleran *dakəl 'big'.

213. 'boil (n.)' *pasa SA

See PPH *pəRsa 'boil (n.)'

\section{Central Agta}

214. 'dry in sun' *sibay

See $\mathrm{PPH}$ *silaR 'sunshine, shiny' and North Alta sinag ‘sun, day'.

215. 'spouse' *bab[ia]

See PPH *bana 'husband'; also Buhid babay 'spouse'.

216. 'pregnant' *bəsu

This may be related to PPH *bəsuR 'full, sated'.

\section{Sinauna}

217. 'boil (n.)' *karapas

This is possibly from *kali-pəRsa 'boil (n.)'; see Central Agta kulipos (< *kəlipəs) ‘boil (n.)’.

218. 'call' *[aə]ta

See $\mathrm{PPH}$ *tawaR 'call'.

\section{Conclusion}

My earlier papers on the Negrito languages of northern Luzon focused first on the analysis of their inherited vocabulary to determine their subgrouping relationships visà-vis non-Negrito languages (Reid 1987, 1989a, 1991; Headland and Reid 1989, 1991). Subsequent work has considered the implications for language contact of borrowed vo- 
cabulary in the Negrito languages (Reid 1989b). This paper examines the vocabulary that is neither clearly inherited nor borrowed from non-Negrito languages, but that appears to be unique to one or more of the Negrito languages.

I propose that the significant body of unique terms in Negrito languages, a fairly substantial number of which are part of the environment in which Negritos presumably lived and which tend to be culture specific (for example, abaca, rattan, sugarcane, coconut, betel leaf, rat, snake, buffalo, deer, dog, locust, crocodile, butterfly, termite, ant, mosquito, and so forth) or "secret" language (such as vagina, penis, and so forth), and many of which are shared exclusively among Negrito languages, possibly constitute an early Negrito substratum in these languages.

I am claiming that these forms are potential evidence of an early pidgin or trade language, subsequently creolized, which was developed by the Negritos to facilitate communication with in-migrating Austronesians.

The fact that Negrito languages today do not show typical features of pidgins or creoles such as limited vocabulary and simplified syntax is no proof that they did not start out in this way. The process of decreolization or adaptation to the status language over thousands of years has long since resulted in their developing all the morphology and syntax that characterize most other Philippine Austronesian languages.

The lexicon of a pidgin typically is constituted of forms from both of the languages that are in contact, although one, usually the status language, dominates, especially for basic or core vocabulary. I am assuming that the language of the Austronesians was the status language in this contact situation, and in fact we find a number of apparently very early Austronesian terms retained in the Negrito languages that have been lost in most of the non-Negrito languages of the Philippines, or retained only in geographically very distant languages.

Other explanations for all these facts are available, such as language shift following a period of bilingualism, but if we bring into consideration what is generally understood to be the prehistoric situation in the Philippines, with culturally more advanced Austronesians moving in as rice-growing colonizers, and needing the assistance of local laborers (whose languages they could not possibly have understood) to clear rainforest and develop fields, we can see that the prerequisites for the development of a pidgin were present. The data presented in this paper seem to me to have their surest explanation then as evidence for a pidgin, given that other grounds also lead us to expect such 
a form of speech to have been present in the early stages of Austronesian-Negrito contact. Unfortunately they also provide evidence that prior to the arrival of non-Negritos, the Philippine Negritos were speaking languages that were not Austronesian. ${ }^{45}$

45 The strength of the major hypothesis of this paper depends crucially on the absence of recognizable cognates of Negrito lexical items in Austronesian languages. Since the earliest versions of this paper, many forms from my original data have been shown in fact to have Austronesian cognates, and have therefore been eliminated from the list. I would like to encourage readers to send me information on other apparent cognates that might reduce my list further, and thereby test the hypotheses. 


\section{Appendix A: Sources}

The following is a list of all Negrito-language wordlists that have been used in the lexical comparisons cited in this paper. They are organized as follows: Commonly used ethnonym; wordlist abbreviation; geographical location where list was collected; source. The source abbreviations are as follows:

PML $\quad$ Philippine minor languages (Reid 1971)

SIL $\quad$ Files of the Summer Institute of Linguistics, Philippines

TNH A Dumagat (Casiguran)-English dictionary (Headland and Headland 1974)

LAR Reid, fieldnotes (1987, 1990, 1993)

FAY A comparative study of Philippine lexicons (Yap 1977)

RBF Robert B. Fox, unpublished wordlist

WP Wesley Petro, unpublished wordlist

All of the wordlists form part of the Pacific and Asian Language Archive (PALA) of the University of Hawai' $i$, an online database accessible to all researchers.

\section{Wordlists for Northern Agta}

\section{Northern Cagayan (NC)}

Atta; ATT; Pamplona, Cagayan; PML

Agta, AGTNC1; Palawi Island, Cagayan; SIL

Agta; AGTNC2; Santa Clara, Gonzaga, Cagayan; SIL

Agta; AGTNC3; Barongagunay, Santa Clara, Santa Ana, Cagayan; SIL

Agta; AGTNC4; Gonzaga, Cagayan (Dupaningan); LAR

\section{Central Cagayan (CC)}

Agta; AGTCC1; Gattaran, Cagayan; PML

Agta; AGTCC2; Gattaran (?), Cagayan; SIL

Agta; AGTCC3; Yaga, Gattaran, Cagayan; SIL

Agta; AGTCC4; Tanglagan, Gattaran, Cagayan; SIL

Agta; AGTCC5; Mammit, Cagayan; SIL

Agta; AgTCC6; Camonayan, Baggao, Cagayan; SIL

\section{Eastern Cagayan (EC)}

Agta; AGTEC1; East Coast Cagayan; SIL

Agta; AGTEC2; Bolos Point, Cagayan; SIL

Agta; AGTEC3; Valley Cove, Cagayan; SIL

\section{Southern Cagayan (SC)}

Agta; AGTSC1; Minanga, Peñablanca, Cagayan; SIL

Agta; AGTSC2; Conyan, Minanga, Peñablanca, Cagayan; SIL 
Agta; AGTSC3; Sapinit, Maconacon, Cagayan; SIL

Agta; AGTSC4; Makagaw (Dupaninan), Cagayan; SIL

Southern Isabela (SI)

Agta; AGTSI; Dikamey, Cauayan, Isabela; SIL

Aurora (AU)

Agta; AGTAU; Casiguran, Aurora; PML and TNH

\section{Wordlists for Arta}

Arta; ART1; Maddela, Quirino; SIL

Arta; ART2; Villa Santiago, Aglipay, Quirino; LAR

Wordlists for Alta

Northern Alta (NA)

Alta; AltN1; Baler, Aurora; MV

Alta; ALtN2; Ditailin, Maria Aurora, Aurora; RBF

Alta; ALTN3; Malevida, Dianawan, Maria Aurora, Aurora; LAR

Alta; AlTN4; Diteki, San Luis, Aurora; LAR

\section{Southern Alta (SA)}

Kabuluen; ALTS1; Rio Chico, Gen. Tinio, Nueva Ecija; WP

Kabuluen; ALTS2; San Miguel, Rio Chico, Gen. Tinio, Nueva Ecija; LAR

Kabuluen; ALTS3; Dikapanikian, Dingalan, Quezon; LAR

Dumagat; ALTS4; Sibul Springs, San Miguel and Pinaganakan, Norzagaray, Bulacan; LAR

\section{Wordlists for Central Agta (AgtUm)}

Dumagat; AGTUm1; Umiray, Quezon; SIL

Dumagat; AGTUM2; Umiray, Quezon; SIL

Dumagat; AGTUm3; Umiray, Quezon; SIL

Dumagat; AGTUm4; Dibut, San Luis, Aurora; LAR

Dumagat; AGTUm5; Bunbun, Panakulan, Polillo, Quezon; LAR

\section{Wordlists for Southern Agta}

\section{Camarines Norte (CN)}

Agta; AgtCN; Villa Bilin, Camarines Norte; SIL

\section{Camarines Sur (CS)}

Rugnot; AGTCS1; Lake Buhi, Camarines Sur; SIL

Inagta; AGTCS2; Sta Niño, Hayagan, and Sta Cruz, Ipil, Buhi, Camarines Sur; SIL

Inagta; AGTCS3; San Augustine, Buhi, Camarines Sur; SIL

Inagta; AGTCS4; San Ramon Lake Buhi, Camarines Sur; SIL 


\section{Wordlists for Sinauna}

Sinauna Tagalog; Sin1; Tanay, Rizal; FAY

Remontado; SIN2; Paimahuan, Limoutan, Gen. Nakar, Quezon; SIL

\section{Wordlists for Ayta}

Aeta; SBL1; Botolan, Zambales; PML

Sambal; SBL2; San Carlos, Zambales; SIL

Sambal; SBL3; San Carlos, Pangasinan; SIL

Sambal; SBL4; Masinloc, (?); SIL

Ambalà; SBL5; Maliwacat, Cabalan, Olongapo, Zambales; SIL

Ambalà; SBL6; Batong Kalyo (Pili), San Marcelino, Zambales; SIL

Magbikin; AYT1; Kanáwon, Morong, Bataan; SIL

Magbikin; AYT2; Bayanbayanan, Magbikin, Mariveles, Bataan; SIL

Balugà; AYT3; Camatsili, Florida Blanca, Pampanga; SIL

Ayta; AYT4; Kakilingan, (?); SIL

Ayta; AYT5; Lumibao, Pampanga (?); SIL

Ayta, Аүт6; Ma-ague-ague, (?); SIL

\section{Wordlists for Negrito languages in Palawan and Mindanao}

Batak; BTK; Palawan; PML

Mamanwa; MMN; Agusan; PML

Ata Manobo; MвоA; Mansalinao, Davao; PML 


\section{Appendix B: Reconstruction Data}

It should be noted that the reconstructions cited here are not all being claimed as uniquely Negrito. Some of them have been reconstructed by Dempwolff, Dyen, Blust, and others for one or more of the early stages of Austronesian. What is of interest with these forms is that their reflexes are limited in Luzon to one or more of the Negrito languages, and that in a number of such cases, other reflexes are found only in a few geographically remote languages of Palawan or Mindanao.

\begin{tabular}{|c|c|c|c|}
\hline 159 & 'abaca' & *arutay & $\begin{array}{l}\text { AGTAu qahutáy, AltN3, } 4 \text { adu?tay, AGTUm3, } 4 \text { arotay, SIN2 aru- } \\
\text { tay }\end{array}$ \\
\hline 34 & ‘accompany' & *ilan & AltN3, 4 élan, AlTS2 kákaylan \\
\hline 68 & 'afternoon' & (ma-)*lutəp & ART malutəp \\
\hline 174 & 'all' & *əl(-an) & ALTN2, 4 alán, 3 alán \\
\hline 100 & 'ant' & *il[əu]m & ALTS2, 4 ilóm, 3 ilúm \\
\hline 69 & 'arrive’ & *digdig & ART dumigdig \\
\hline 3 & 'ashamed' & *aməs & $\begin{array}{l}\text { AGTCC1 mamıt, } 2 \text { ma:mat, AlTN2 amáməs, } 3 \text { ma?a-máməs, } 4 \\
\text { məجamáməs, AGTUM3, } 4 \text { mamamos, } 5 \text { nagkam-mamos }\end{array}$ \\
\hline 168 & 'back' & *səpan & AGTNC1, 2, 3, CC4, 6, EC3 sıppay, SC2 suppáy, ART sapáy \\
\hline 209 & 'bad' & *balayu & ART balápu \\
\hline 177 & 'bathe' & *dimuy & $\begin{array}{l}\text { AGTSI mégdimoy, ART majdimuy, ALTS } 2 \text { mandímoy, } 3 \text { nundimuy, } 4 \\
\text { mandímuy }\end{array}$ \\
\hline 32 & 'betel leaf' & $*$ li $[\mathrm{t}]$ lit & ALTN2 litlít, 3, 4 litlit, АYT2 lilit \\
\hline 212 & 'big' & *damanta & ALtS2, 3 demanta \\
\hline 194 & ‘big' & *haya & AltS4 hayá, AGTUm3, 4, 5 haya \\
\hline 41 & ‘bitter’ & *təkak & $\begin{array}{l}\text { AGTCC3 mıtıkkat, 4, NC1, } 2 \text { mıtıkkak, CC6, EC1, 2, } 3 \text { makkak, } \\
\text { NC3 mıkkak, SC2, 3, } 4 \text { makak }\end{array}$ \\
\hline 101 & 'black' & *lit[əu]b & ALTS2 nalitob, 3 nalitób \\
\hline 102 & 'blow (v.)’ & *uswa & AltS2 immuswa \\
\hline 213 & 'boil (n.)' & *pasa & ALTS2, 3, 4 pása \\
\hline 217 & 'boil (n.)’ & *karapas & SIN1, 2 karapas \\
\hline 17 & 'boil (v.)’ & *ləbut & $\begin{array}{l}\text { AGTCC3 mıglabut, 4, NC1, 2, } 3 \text { mıglıbbut, CC6 maglıbbut, EC1 } \\
\text { maglabut, 2, } 4 \text { maglabbut, } 3 \text { lombut, SC1 paglabbutan, } 2 \text { maglabbút, } \\
3 \text { maglabbut, SI paglabutən, Au labut, ALTN3 labut, } 4 \text { lumalbut }\end{array}$ \\
\hline
\end{tabular}




\begin{tabular}{|c|c|c|c|}
\hline 128 & 'bone' & *kaks(-an) & AGтUм3, 4, 5 kaksan \\
\hline 70 & 'bone’ & *sagnit & ART sagnit \\
\hline 193 & 'bring' & *[aə]da & AltN3 adən, 4 əddənan, AGTUм3, 4 addi, 5 majadde \\
\hline 15 & 'build fire' & *dukut & AGTAu dukot \\
\hline 103 & 'burn' & *tiduk & ALTS1 tadok, 2 matedok, 3, 4 matédok \\
\hline 84 & ‘burn’ & *təmuk & AltN3 tamu?, 4 matmu? \\
\hline 104 & 'bury, inter' & *laba & ALTS2, 4 lábe \\
\hline 5 & 'bury, inter' & *tapuR & $\begin{array}{l}\text { AU tapoh 'to cover over; to fill a hole with dirt until level', ALTS3 } \\
\text { itapul, AGTUM3, } 4 \text { tapurin }\end{array}$ \\
\hline 105 & 'butterfly' & (ma-)*lawak & ALTS2, 3 malawák \\
\hline 42 & 'butterfly' & *lilli & AgtCC6, NC3, EC3, SC4 lilli, EC1 léley, NC4, EC2 lelle \\
\hline 42 & 'butterfly’ & *lullu & AGTSC2, 3 lóllo, 1, 4 lollo \\
\hline 59 & 'butterfly' & *limlim & CC3 lemlem \\
\hline 59 & 'butterfly’ & *lumlum & AGTCC1, 2, 5 lomlom \\
\hline 71 & 'butterfly' & *pippun & ART peppun \\
\hline 23 & 'buttocks' & *sula & AltS4 sula, AGTUm3, 4, 5 sula \\
\hline 106 & 'buttocks' & *timuy & AltS2, AgTSC3 timoy \\
\hline 218 & 'call' & *[aə] ta & Sin1, 2 ata?an \\
\hline 57 & 'call' & *dulaw & AGTSC1 dulawın, 2 dulawán, 3, 4 dulawan, Au duláw \\
\hline 107 & 'call' & *gawi & ALtS2 géwyan, 3, 4 gewyan \\
\hline 85 & 'call' & *yuk & ALtN2 yóPan, 3 go?, 4 go?an \\
\hline 129 & 'call' & *ulay & AGtUм3, 4, 5 ola \\
\hline 108 & 'carabao' & *udup(-an) & ALtS2, AGTSC3, 4 uddúyan \\
\hline 193 & ‘carry' & $*$ [aə]da & AgtUm3, 4 addi, 5 mayadde \\
\hline 169 & 'cheek' & $(\mathrm{pa}-)^{*}$ sinil & AltN2 pasépil, AltS2, 3, 4 pasinil, AGTUM3, 4, 5 pasinil \\
\hline 172 & 'chicken' & *kati & AGTSI kati \\
\hline 153 & 'child' & *ubun & SiN1, 2 ubon \\
\hline 160 & 'chin' & *səlan & $\begin{array}{l}\text { AgtCC6, NC1, 3, EC2, } 3 \text { sıllay, } 1 \text { salay, AltN2 saláy, } 3 \text { saláy, } \\
\text { AltS2, 3, } 4 \text { sollay }\end{array}$ \\
\hline 178 & 'choose' & *pa?ita & AltS2 maméta, 3, 4 pumeta, AGTUm gepeta \\
\hline 130 & 'climb’ & *dawit & AgтUм3, 4 dumáwet, 5 dumawet \\
\hline
\end{tabular}




\begin{tabular}{|c|c|c|c|}
\hline 86 & ‘collapse’ & *bəwəl & ALTN3 miníbwal, 4 minébwal \\
\hline 131 & 'crocodile' & (may-)*atu & AgtUm3, 4, 5 mayatu \\
\hline 180 & 'crocodile' & *bukarut & $\begin{array}{l}\text { AGTNC1, EC2 bukırot, CC3, SC1 bukıhot, CC4, 4, EC1, 3, SC3, } 4 \\
\text { bukahot, NC2, 3, } 4 \text { bukarot, SC2 bukahót, Art bukarút }\end{array}$ \\
\hline 109 & ‘cry’ & *kəbi & ALTS2, S3, S4 kumbi, kumukbi \\
\hline 189 & ‘cry’ & *siak & ART mansía, mansiá, ALTN2 sumíya?, 3 siya?, 4 mənsíya? \\
\hline 175 & ‘cut, slice' & *gəlgəl & $\begin{array}{l}\text { AGTNC1, 3, CC1, 3, 4, SC1 mgg^lg^l, NC2 g^lg^lıy, CC2 maggalgal, } \\
\text { 6, EC2, } 3 \text { magg^lg^l, EC1, SC3, SI, Au galgal, SC2 maggalgal, } 4 \\
\text { galgalan, ART galgalan, ALTN3, } 4 \text { galgal }\end{array}$ \\
\hline 110 & ‘deep’ & *tanaw & ALTS2, 3 tánaw \\
\hline 165 & ‘deep’ & *salad & $\begin{array}{l}\text { AGTAu disalad 'deep, inside', AltN3 madisalad, } 4 \text { mə-dísalád, } \\
\text { ALTS4 moddisalad, AgtUm3, } 4 \text { madisalad }\end{array}$ \\
\hline 10 & 'deer, buck' & *b[ia]dut & AGTSI, Art bidut, Au bidut 'buck' \\
\hline 87 & ‘depart' & *əg[?k]an & AltN2, 3, 4 umag?áy \\
\hline 167 & ‘depart' & *ginan & ART guminan \\
\hline 185 & ‘dizzy’ & *linug & AGTAU linug \\
\hline 14 & 'dog’ & *lapul & AGTAu lapol 'puppy', ART lappul \\
\hline 72 & ‘drink’ & *tim & ART mattim \\
\hline 185 & ‘drunk’ & *linug & ALTN3 linúg, 4 minalinúg, ALTS4 mollinúg \\
\hline 43 & 'dry in sun’ & *sarun & $\begin{array}{l}\text { AGTNC1, 3, } 4 \text { isıron, CC6 isıhon, EC1, 2, } 3 \text { isáhon, SC3 sahon, } 4 \\
\text { masáhod }\end{array}$ \\
\hline 214 & 'dry in sun’ & *sibay & AGTUM3, 4 sibenin, 5 sibayin \\
\hline 73 & ‘ear’ & *ibəy & ART ibəy \\
\hline 190 & 'earth, soil' & *tapək & ART tapá, AlTN2, 3 tapə?, 4 tapá? \\
\hline 182 & 'face' & *mud $[i a] t$ & AGTSI mudet, Art mudít \\
\hline 169 & 'face' & $(\mathrm{pa}-)^{*}$ sijil & ALTS3 pasinil, AGTUM3, 4 pasinil \\
\hline 111 & 'fall (v.)' & *pagpag & ALTS2, 3, 4 mapagpag \\
\hline 24 & 'fast' & *paripari & ALTS4, 3 moppalipáli, AGTUM3 maparipari, 4 paripari \\
\hline 16 & 'feather' & *pulug & ART pulúg \\
\hline 132 & 'feather' & *putput & AGTUM3, 4 putput \\
\hline 163 & 'feather' & *olad & AGTNC1, 3, 4, CC3, 4, 5, 6, EC2, 3 ıllad, NC2 ıllád, SC2 allád \\
\hline 199 & 'fever' & *pənay & ALTN3, 4 mepanáy \\
\hline
\end{tabular}




\begin{tabular}{|c|c|c|c|}
\hline 112 & 'fight, quarrel' & *itaw & AltN3 Pitaw, 4 ma?PiPitaw \\
\hline 51 & 'fingernail' & $* l u$ & AgtCC1, 2 lu \\
\hline 51 & 'fingernail' & *[1] udis & AGTNC2 lúdis, CC3, 4 ludis, NC3, CC6, EC2, 3 udis \\
\hline 113 & 'fingernail' & *lunu & AlTS2, 3 lunu, 4 lunú \\
\hline 11 & 'fingernail' & $*[1]$ usip & AGTEC2, 3, SC2 usep, Art lusip \\
\hline 149 & 'fire' & *adin & AGTCS1, 4 adín, CS3 adin \\
\hline 15 & 'fire' & *dukut & ART dut \\
\hline 166 & 'fly (v.)’ & *əbər/*igbər & $\begin{array}{l}\text { AGTNC1 umbır, } 2 \text { umbar, } 3 \text { umebar, SI umbəh, AU egbah, CC1 } \\
\text { imubıh, } 2 \text { imubah, } 3 \text { imubar, } 4 \text { umubah, } 6 \text { umebbıh, EC2 umegbır, } \\
3 \text { umbıh, SC1 umebbar, } 2 \text { umbah, } 4 \text { umebah, AlTN inombal, ALTS } \\
\text { umigbol, ART umbar }\end{array}$ \\
\hline 184 & 'forehead' & $* \mathrm{k}[\mathrm{i} \partial] \mathrm{d} ə \mathrm{p}$ & Au kidáp, ALTN3, 4 idáp, ALTS2, 3, 4 koddop \\
\hline 20 & 'forehead' & $*[1]$ anas & 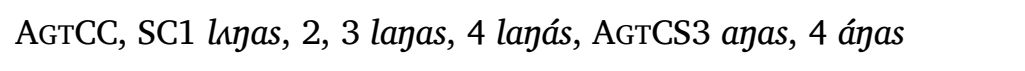 \\
\hline 18 & 'forget' & *liksap & AGTAu leksapán, ALtN2 minali?sapán, 3 li?sap, 4 máli?-sapán \\
\hline 22 & 'fragrant' & *səlub & ART messalúb, ALtN3 mıslob, 4 maslob \\
\hline 88 & 'fruit' & *ian & ALTN2, 3 iyán, 4 ián \\
\hline 197 & 'girl' & (ma-)*huna & ALTS2, 4 mahona \\
\hline 133 & 'hair' & *sapuk & AGTUM3, 4 sapok \\
\hline 16 & 'hair' & *pulug & ART pológ \\
\hline 187 & 'hard (thing)' & *kətug & AGTAu katóg, AltN2 mə?túg, 3 mı?tog, 4 məPtug \\
\hline 64 & 'hear' & *sanig & AGTSC1 sanigın, 2 sasanigən, 3 magsánig \\
\hline 89 & 'hear' & *tibəy & 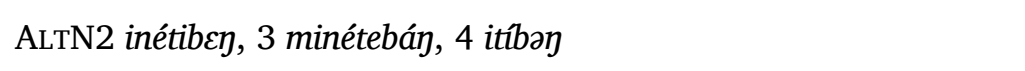 \\
\hline 44 & 'hear' & $* \operatorname{tima}[\mathrm{n}, \mathrm{y}]$ & $\begin{array}{l}\text { AGTCC3 mıgtimay, } 4 \text { mıgtiman, 6, NC1, } 3 \text { matiman, } 2 \text { na-timán, } \\
\text { EC1 matimay, 2, } 3 \text { nıtiman, SC4 mateman }\end{array}$ \\
\hline 39 & 'heavy' & *dəgi & $\begin{array}{l}\text { AGTNC1, 2, 3, 4, CC3, 4, 6, EC3, SC1 mıdıggi, EC1 ma-dagge, } 2 \\
\text { mıdngge, SC2, } 4 \text { madaggi, } 3 \text { medaggi, Au dagé }\end{array}$ \\
\hline 183 & 'heavy' & *dətun & AGTSI madaton, ART medattun, medadtun \\
\hline 90 & 'hit, strike' & *pu[?k]na & ALTN3 minápu?na, 4 pinu?nah \\
\hline 199 & 'hot' & *pənay & AltS2, 3, 4 mopnay \\
\hline 134 & 'hunt' & *ikag & AGTUM3, 4 magPikag \\
\hline 45 & 'hunt' & *lagum & AGTNC1, 2, 3, CC6 mıglagum, EC2 mıgagum, 3 lagum \\
\hline
\end{tabular}




\begin{tabular}{|c|c|c|c|}
\hline 9 & 'hunt' & *purab & $\begin{array}{l}\text { AGTSC1, 2, 3, } 4 \text { mamuhab, ART mamurab 'hunt with bow and ar- } \\
\text { row' }\end{array}$ \\
\hline 160 & 'jaw’ & *səlan & 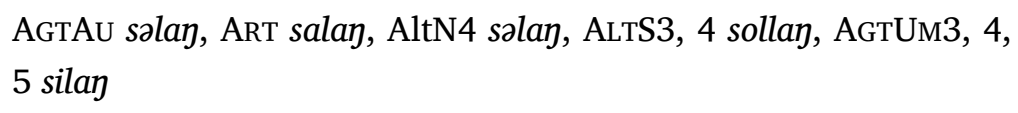 \\
\hline 6 & 'kind' & *Rəbi & ART me?arbi \\
\hline 35 & 'know' & *ənul & ALtN3 annúlən, 4 ənnúlən, AltS2 onólon, 3, 4 onnólan \\
\hline 25 & 'know' & *abuyan & ALTS3 abuyanan, 4 o??abuyanan, AGTUм peabuyenan \\
\hline 135 & 'ladle' & *lukuy & AGtUm3, 4, 5 lukoy \\
\hline 207 & 'ladle' & *tug & AGTSI tog \\
\hline 36 & 'lazy’ & *b[ia]kət & AltN3, 4 mabírat, AltS3 bikot \\
\hline 26 & 'leaf' & *agid & AltS2, 3, 4 ágid, AGTUm3, 4, 5 agid \\
\hline 154 & 'leaf' & *hayin & SiN1 hayin \\
\hline 91 & ‘lie down’ & *ədsay & ALtN3, 4 umadsay \\
\hline 74 & 'lime’ & *yusu & ART yusú \\
\hline 92 & 'locust' & *pəsal & AltN3, 4 passal \\
\hline 114 & 'loincloth’ & *g[ia]nat & ALTS2, 3 gínat, 4 ginat \\
\hline 93 & 'long' & *lə[?k]aw & ALtN3 mala??aw, 4 mala??aw \\
\hline 136 & 'long (time)' & *luy & AGTUM3, 4 naloy \\
\hline 115 & 'long (time)' & *təwali & ALTS2 motwali, motweli, 3 natweli, 4 motwali \\
\hline 198 & 'love' & *bud[ia] & AltN3, 4 budin, AltS2 obbudin, 3 mabudi, 4 bumbudi \\
\hline 75 & 'man, male' & *gilan(-an) & ART gilayán \\
\hline 27 & 'man, male' & *patud & ALTS2, 4 patúd, AGTUм patud \\
\hline 179 & 'monkey’ & *burug & $\begin{array}{l}\text { AGTNC1, 3, EC2 burog, CC3 buróg, 4, 6, EC1, 3, SC1, 2, 3, 4, SI } \\
\text { buhog, NC2 buhóg, Au buhóg, ART buróg }\end{array}$ \\
\hline 76 & 'mosquito' & *bunur & ART buyúr \\
\hline 150 & 'mosquito' & *kubun & AGTCS3 koboy (See footnote 33) \\
\hline 46 & ‘mountain' & *amugud & AGTNC1, 2, 3, 4, CC5, EC2, 3, SC4 amugud \\
\hline 204 & 'mud' & *ludəg & AGTCC6, 4, EC3 lodıg, SC2 aludag, 3 lóddag \\
\hline 206 & 'mud' & *lukit & AGTNC1, 3 loket, 2 maloket \\
\hline 191 & ‘near' & *lutit & AltN2, 3 lutít, 4 malútit, AltS2, 4 lútit, S3 lutit, AGTUm3, 4, 5 lutit \\
\hline
\end{tabular}




\begin{tabular}{|c|c|c|c|}
\hline 176 & 'near' & *b[ia]kən & 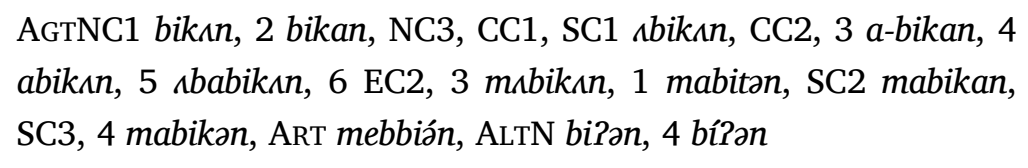 \\
\hline 210 & 'night' & *bajwət & ART bínuat \\
\hline 137 & 'no, not' & *eyen & AgtUm3, 4, 5 eyen \\
\hline 47 & 'old (obj.)' & *ligid & AGTNC1, 3, CC6, EC2, 3, SC1, 3, 4 alegid, CC4, NC2 legid \\
\hline 77 & 'old (man)' & *dupu & ART dupú \\
\hline 195 & 'old (woman)' & *gupad & ALTS2, 3, 4 gupad \\
\hline 78 & 'one' & *sipan & ART sípay \\
\hline 116 & 'other (diff.)' & *kalad & ALTS2, 3, 4 kalád \\
\hline 11 & 'penis' & *g[ia]ləy & AGTSI gilay, Au giláy, Art gilay \\
\hline 94 & 'penis' & *gəyət & AlTN4 gәуәt \\
\hline 186 & 'person'46 & *uRdin & AGTNC1, CC6, EC1, 2, SI ogdin, AltN3, 4 uldin \\
\hline 6 & ‘pity’ & *Rəbi & $\begin{array}{l}\text { AgtAu kagbi, ART pagarbián, AltN3 Palbi, } 4 \text { maPalbih, AltS2, 3, } 4 \\
\text { mokkalbi, AGtUm3, 4, } 5 \text { kalbi }\end{array}$ \\
\hline 138 & 'pound' & *buntul & AGTUм3, 4, 5 magbuntul \\
\hline 216 & 'pregnant' & *bəsu & AGtUм3, 4, 5 mabsu \\
\hline 37 & 'pregnant' & *tuyud & ALTN3 matóyod, 4 matúyud, ALTS3 mottuyud \\
\hline 117 & 'put, place' & *bənu & AltS2, 3, 4 ibno \\
\hline 95 & 'put, place' & *dətun & ALTN3 idton, 4 idtun \\
\hline 118 & 'rain' & *dəsu & AlTS2 dumudsu, 3, 4 dumsu \\
\hline 173 & 'rain' & $* \mathrm{~g}[\mathrm{ia}] \mathrm{mis}$ & AGTCN gemes \\
\hline 79 & 'rain' & *punəd & ART púnad \\
\hline 139 & 'rain' & *tapuk & AGTUM3, 4 tapúk, 5 tapuk \\
\hline 208 & 'rat' & *bukət & AGTSI bukat, Au bukat 'mouse' \\
\hline 2 & 'rat' & *kuyəy & 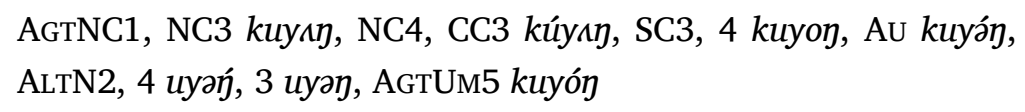 \\
\hline 65 & 'rattan' & *karat & AGTSC1 kıhat, 2 kahat \\
\hline 1 & 'rattan' & *lati & $\begin{array}{l}\text { AGTNC1, 3, 4, CC4, 6, EC2, 3, SC1 lati, NC2 latí, CC3 láti?, EC1 } \\
\text { late, Art latí, AltN3 láti, } 4 \text { latíh, AltS2 lattir, } 3 \text { láti, } 4 \text { lati, AGTUM3, } \\
\text { 4, } 5 \text { lati }\end{array}$ \\
\hline
\end{tabular}

${ }^{46}$ Only used of non-Negritos. 


\begin{tabular}{|c|c|c|c|}
\hline 164 & 'red' & *dadag & $\begin{array}{l}\text { AGTCC1 d^hag, } 2 \text { daha:g, CC6, EC2, } 3 \text { mıdideg, SC2, } 4 \text { madideg, } \\
\text { Au medidég, ALTS3 maderag, AGTUM3, 4, } 5 \text { maderag }\end{array}$ \\
\hline 96 & 'red' & *silit & ALtN2 maslít, 3 masilit, 4 maslit \\
\hline 170 & 'river' & *la?u & ALTS4 lo?o, Sin2 lao \\
\hline 147 & 'river' & *urat & AgTUM3, 4, 5 órat \\
\hline 188 & 'river' & *wagət & ART wagat, AlTN2, 4 wagát, 3 wagat, AlTS2, 3 wagot, 4 wagút \\
\hline 52 & 'run' & *buyut & $\begin{array}{l}\text { AGTNC1, 3, CC4 bumuyot, NC2 bumúyot, CC6, EC3 bu-moyot, } 2 \\
\text { magbuyot }\end{array}$ \\
\hline 140 & 'run’ & *g[ia]kan & AGTUM3, 4 gikan \\
\hline 167 & 'run' & *ginan & AGTSI ginay, Au gináy, ALTN4 məygínan, 2 ginán \\
\hline 80 & 'run' & *gurugud & ART maggurugúd \\
\hline 66 & 'run’ & *gutuk & AGTSC1 maggutok, 2, 3, 4 gumutok \\
\hline 31 & 'run' & *kaldit & ALTS2, 3, 4 kumaldit, CN kaldit \\
\hline 67 & 'salt' & *b[ia]gəl & AGTSC1 big^l, 2 bigal \\
\hline 141 & 'sand' & $* \operatorname{layg}[\mathrm{ia}] \mathrm{s}$ & AGtUм3, 4 langis, 5 langes \\
\hline 81 & 'say, tell' & *bud & ART ibud \\
\hline 178 & 'say, tell' & *pa?ita & $\begin{array}{l}\text { AGTNC1, CC5, NC3, EC3 ipetı, CC4, 6, EC2, SC2, 3, } 4 \text { ipeta, NC2 } \\
\text { ipéta }\end{array}$ \\
\hline 158 & 'see’ & *ələw & AYT5 maəlawan, 6 iliwán \\
\hline 28 & 'see' & *lawi $[\mathrm{g}]$ & $\begin{array}{l}\text { ALTS2 panláwin, } 3 \text { lawin, } 4 \text { lawín, AGTUM3, } 4 \text { pelawigin, pagela- } \\
\text { wegín }\end{array}$ \\
\hline 97 & ‘seek' & *alyuk & ALtN3 alíu?, 4 məநáliu? \\
\hline 181 & 'short (obj.)' & *pirit & AGTSC1 apehit, SI apehet, AU apéhit, ART apírit \\
\hline 56 & 'shoulder' & *dapi & AGTNC1 dspi, EC3 dapi \\
\hline 151 & 'shoulder' & *mugmug(-an) & AGTCN mugmugen \\
\hline 30 & 'shoulder' & *subuy (-an) & ALTS2 sóboyan, 3, 4 sóbuyan \\
\hline 30 & 'shoulder' & *sugbuy & AGTCS3 sogbón, 4 sógboy (See footnote 17) \\
\hline 162 & 'sit' & *iknud & $\begin{array}{l}\text { AGTNC1, EC2 mıgetnod, NC2 magéknod, meknod, } 3 \text { met-nod, CC6 } \\
\text { umetnod, EC1 magiknod, } 3 \text { magitnod, SC1 ma-gitnud, 2, } 3 \text { magetnod, } \\
4 \text { megetnod, SI eknud, Au iknód, ALTN2 umítnud, 3, } 4 \text { umitnud }\end{array}$ \\
\hline 119 & 'sit' & *layad & Alt2, 3, 4 lumayád \\
\hline 142 & 'sit' & "lipa & AgtUм3, 4, 5 lumipa \\
\hline
\end{tabular}




\begin{tabular}{|c|c|c|c|}
\hline 155 & 'sit' & *sona & SIN1, 2 mamasna \\
\hline 60 & 'sit' & *tugkuk & AGTCC2 magtogkok, 3, 4, 5 mıgtogkok \\
\hline 171 & 'skinny' & *rasa & $\begin{array}{l}\text { AGTNC1 mırası, 2, SC3 mahása, NC3 marası, CC4 mahasa, 6, } \\
\text { EC2, 3, SC1 mıhası, EC1 məhasa, SC4 mahasa, SI məhasa }\end{array}$ \\
\hline 205 & ‘sky’ & *lakup & NC1, 2 lakop, 4, EC2 lakóp \\
\hline 82 & ‘sleep’ & *idəm & ART médəm \\
\hline 152 & ‘sleep’ & *lubat & AGTCN lubet \\
\hline 143 & ‘sleep’ & *pida & AgtUм3, 4, 5 pede \\
\hline 38 & ‘sleep’ & *puləd & AltN3, 4 mapólad, ALtS2, 3, 4 mapulád \\
\hline 200 & 'small (obj.)’ & *bəlik & $\begin{array}{l}\text { AGTNC1, } 3 \text { bıllek, ballik, CC3 bılit, 4, SC4 ballik, CC6, EC2, 3, } \\
\text { SC1 bıllik, EC1, SI balek, SC3 ballík }\end{array}$ \\
\hline 7 & ‘snake’ & *babak & AltS3, 4 bebek, AGTUм3, 4, 5 bebek, Sin1 babák \\
\hline 215 & 'spouse' & *bab[ia] & AgtUм3, 4, 5 bebi \\
\hline 98 & 'stand' & *payun & AltN2, 4 pumáyoj, 3 pumayu \\
\hline 120 & 'stand' & *piad & ALTS2 pumiyad, 3 pumiyéd, 4 pumiád \\
\hline 144 & 'stand' & *[uə] di & AGTUм3, 4 umuddi, 5 umuddí \\
\hline 201 & 'star’ & *pu[st]ian & AGTNC1, 3, 4, CC6, EC1, 2, 3, SC2, 3, 4 pusiyan, CC4 pi-siyın \\
\hline 156 & ‘stone’ & *igay & Sin1 ígay, 2 igáy \\
\hline 21 & 'summit' & *kurut & $\begin{array}{l}\text { AGTNC1, 2, 3, CC3, } 4 \text { kurot, NC4 kurót, CC5 kurut, 6, EC2, 3, SC1, } \\
\text { 2, 3, } 4 \text { kuhot }\end{array}$ \\
\hline 19 & 'summit' & *ta[ly]tay & AgtAu taytáy, AltS2, 3, 4 taltay \\
\hline 48 & ‘sun' & *pamalak & AGTNC1, 2, 3, 4, CC3, 4, EC2, 3 p^mılık, SC2, 3, 4 pa-malak \\
\hline 145 & ‘sweat' & *ald [ia]t & AGTUM5 aldet \\
\hline 145 & 'sweat' & *aldut & AGTUM3, 4 aldut \\
\hline 58 & 'sweat' & *asub & AGTSI $a s o b$, AU asób \\
\hline 192 & 'sweat' & *lanis & ALTN2 molánis, 3, 4 malánis \\
\hline 202 & 'tail' & *bunid & AGTNC1, 3, CC4, 6, EC1, 2, 3, SC2 buned, NC2 bunéd \\
\hline 121 & 'tail' & *lambuy & ALtS2, 3 lambuy \\
\hline 49 & 'termite' & *sarik & $\begin{array}{l}\text { AGTNC1, } 3 \text { sırek, NC2 sarék, CC6, EC2, 3, SC2, 3, } 4 \text { sa-hek, } 1 \\
\text { sıhek }\end{array}$ \\
\hline 40 & 'thick' & *bagəl & $\begin{array}{l}\text { AGTNC1, 3, CC3, 4, EC2, 3, SC1 mıbig^l, NC2 mabégor, EC1, SC3, } \\
4 \text { mabigél, } 2 \text { mabigal, Au bagál }\end{array}$ \\
\hline
\end{tabular}




\begin{tabular}{|c|c|c|c|}
\hline 61 & 'thirst' & *g[ia]mtay & AGTCC1 gimtay, 2 gimtáy \\
\hline 8 & 'thirst' & *pələk & AGTEC1 maplək, AGTAu éplək, ART me?ipla \\
\hline 122 & 'three' & *sanay & AGTS4 sayay \\
\hline 54 & 'throw' & $* b[\mathrm{ia}] \mathrm{sag}$ & AGTCC6, EC2 ibisag, EC1 bisag, EC3 bisag^n, SC3, 4 bisa-gan \\
\hline 161 & 'throw' & *but & ALTN3 ibut, AltS2 ibut \\
\hline 50 & 'throw' & *tugbak & $\begin{array}{l}\text { AGTNC2 tóbbak, 3, EC2 itobbak, CC4 mıgtobbak, SC2 i-togbak } \\
\text { (note also CC3 itıbık) }\end{array}$ \\
\hline 161 & 'throw away' & *but & $\begin{array}{l}\text { AGTAU ibút, ART ibut, AltN2 ibút, 2, } 3 \text { ibut, AltS2, 3, } 4 \text { ibut, } \\
\text { AGTUM3, } 4 \text { bútin, } 5 \text { but, bobut }\end{array}$ \\
\hline 50 & 'throw away' & *tugbak & $\begin{array}{l}\text { AGTNC2, 3, CC4, EC2 itobbak, } 3 \text { itogbak (note also: ATT itabba?, } \\
\text { CC3 it } b \wedge k \text { ) }\end{array}$ \\
\hline 123 & 'tree' & *lab[ia]t & ALtS2, 3 labét \\
\hline 124 & 'truth' & *kuduR & ALtS2, 3, 4 akudul (note also ART kurúg) \\
\hline 83 & 'two' & *təlip & ART tallip \\
\hline 165 & 'under' & *salad & AltN4 disálad, ALTS4 disalád, AGTUM5 disalad \\
\hline 62 & 'urine’ & *sitəb & AGTCC1, 3, 5 sitnb, 2, sitab \\
\hline 125 & 'vagina' & $(\mathrm{i}-)^{*}$ play & ALtS2, 4 iplay \\
\hline 146 & 'vagina' & *kin(-an) & AGTUM3, 4, 5 kinan \\
\hline 211 & 'vagina' & *sabit & ART sabít \\
\hline 4 & ‘vein' & *litid & AgtAu lítid, AltN3, 4 lítid, AgtUm 5 letid \\
\hline 99 & 'wait' & $*$ tanud & ALTN3, 4 montanúd \\
\hline 63 & 'walk' & *sugut & AGTCC1 mıgtugut, 2 magtugut, 3 mıgsugut \\
\hline 13 & 'wall' & *gəsəd & AGTSI gattad (note also ART gisád) \\
\hline 29 & ‘wall' & *sagbun & ALTS2, S4 sagboy, AGTUM3, 4, 5 sagboy \\
\hline 170 & ‘water’ & $* l a 3 u$ & SiN1 la?u, 2 lao \\
\hline 147 & ‘water’ & *urat & AGTUм3, 4, 5 órat \\
\hline 188 & ‘water’ & *wagət & ART wagat, AlTN2, 4 wagát, 3 wagat, AlTS2, 3 wagot, 4 wagút \\
\hline 33 & 'waterfall' & *gərəy & AGTUM5 goroy, SIN2 garáy \\
\hline 55 & 'waterfall' & *sənad & AGTEC2, SC2, 3, 4 sannad, EC3, SC1 sınnad, SI sənad \\
\hline 196 & 'waterfall' & *tabi & AltS2, 3 tábi, 4 tabi, AGTUM3, 4 tabi \\
\hline 148 & 'white' & *lapsay & AgtUm3, 4, 5 malapsay \\
\hline
\end{tabular}




\begin{tabular}{|c|c|c|c|}
\hline 203 & 'white’ & *pun $[\mathrm{st}] \mathrm{it}$ & $\begin{array}{l}\text { AGTNC2, 3, CC6 ponset, EC2 mıponset, SC3, } 4 \text { maponset (note al- } \\
\text { so AGTEC1, SC2 maponsak, } 1 \text { mıponak) }\end{array}$ \\
\hline 126 & 'widow(er)' & $($ na-)*dit & ALTS2, 4 nádit, 3 nadit \\
\hline 127 & 'wind' & *kabu(-an) & ALTS2 kabuán, 3 kabwen, 4 kabúan \\
\hline 157 & 'wind' & *rugus & SiN1 rugús, 2 irugús \\
\hline 53 & 'wing' & *kəpig & AGTNC3, 4, EC2 kıppeg, EC1 kәpeg, 3 kappeg, SC2, 3, 4 kapeg \\
\hline 163 & 'wing' & *alad & $\begin{array}{l}\text { AGTNC2 allad, CC4, 6, SC1 ^llad, ALTS2 ullad, 3, } 4 \text { ollad, AGTUм1, } \\
3 \text { ilad }\end{array}$ \\
\hline 123 & 'wood' & $* l a b[\mathrm{ia}] \mathrm{t}$ & ALTS2, 3 labét \\
\hline 197 & 'woman' & (ma-)*huna & AGTUM3, 4 mahona, 5 mahoná \\
\hline
\end{tabular}




\section{Appendix C: Index of Reconstructions}

\begin{tabular}{|c|c|c|c|c|c|}
\hline *[aə]da & 'bring, carry' & 193 & *bud[ia] & 'love' & 198 \\
\hline *[aə]ta & 'call' & 218 & *bukarut & 'crocodile' & 180 \\
\hline *abuyan & 'know (s.o.)' & 25 & *bukət & 'rat' & 208 \\
\hline *adin & 'fire' & 149 & *buyur & 'mosquito' & 76 \\
\hline *agid & 'leaf' & 26 & *bunid & 'tail' & 202 \\
\hline *ald [ia]t & 'sweat' & 145 & *buntul & 'pound' & 138 \\
\hline *aldut & 'sweat' & 145 & *burug & 'monkey' & 179 \\
\hline *alyuk & 'seek' & 97 & *but & 'throw, throw away' & 161 \\
\hline *aməs & 'ashamed' & 3 & *buyut & 'run' & 52 \\
\hline *amugud & 'mountain' & 46 & *dadag & 'red & '164 \\
\hline *arutay & 'abaca' & 159 & *damanta & 'big' & 212 \\
\hline *asub & 'sweat' & 58 & *dapi & 'shoulder' & 56 \\
\hline$(\operatorname{may}-)^{*}$ atu & 'crocodile' & 131 & *dawit & 'climb' & 130 \\
\hline *b[ia]dut & 'deer, buck' & 10 & *dəgi & 'heavy' & 39 \\
\hline *b[ia]gəl & 'salt & 67 & *dəsu & 'rain' & 118 \\
\hline *b[ia]kən & 'near' & 176 & *dətun & 'heavy' & 183 \\
\hline *b[ia]kət & 'lazy’ & 36 & *dətun & 'put, place' & 95 \\
\hline *b[ia]sag & 'throw' & 54 & *digdig & 'arrive' & 69 \\
\hline *bab $[\mathrm{ia}]$ & 'spouse' & 215 & *dimuy & 'bathe' & 177 \\
\hline *babak & 'snake' & 7 & (na-)*dit & 'widow, widower' & 126 \\
\hline *bagəl & 'thick' & 40 & *dukut & 'fire, build a fire' & 15 \\
\hline *balayu & 'bad' & 209 & *dulaw & 'call' & 57 \\
\hline *baywət & 'night' & 210 & *dupu & 'old (man)' & 77 \\
\hline *bəlik & 'small (obj.)' & 200 & *əbər & 'fly (v.)' & 166 \\
\hline *bənu & 'put, place' & 117 & *ədsay & 'lie down' & 91 \\
\hline *bəsu & 'pregnant' & 216 & *əg[?k]aך & 'depart' & 87 \\
\hline *bəwəl & 'collapse' & 86 & *al(-an) & 'all' & 174 \\
\hline *bud & 'say, tell' & 81 & *olad & 'feather, wing' & 163 \\
\hline
\end{tabular}




\begin{tabular}{|c|c|c|c|c|c|}
\hline *ələw & ‘see’ & 158 & *il[əu]m & 'ant' & 100 \\
\hline *ənul & 'know' & 35 & *itaw & 'fight, quarrel' & 112 \\
\hline *eyen & 'no, not' & 137 & *kabu(-an) & 'wind' & 127 \\
\hline$* \mathrm{~g}[\mathrm{ia}] \mathrm{mis}$ & 'rain' & 173 & *kaks(-an) & 'bone' & 128 \\
\hline *g[ia]kan & 'run' & 140 & *kalad & 'other (different)' & 116 \\
\hline *g[ia]lən & 'penis' & 11 & *kaldit & 'run' & 31 \\
\hline$* g[i a] m t a n$ & 'thirst' & 61 & *karapas & 'boil (n.)' & 217 \\
\hline$* g[$ ia $]$ nat & 'loincloth' & 114 & *karat & 'rattan' & 65 \\
\hline *gawi & 'call' & 107 & *kati & 'chicken' & 172 \\
\hline *gəlgəl & 'cut, slice' & 175 & *kəbi & ‘cry’ & 109 \\
\hline *gərəy & 'waterfall' & 33 & *kəpig & 'wing' & 53 \\
\hline *gəsəd & ‘wall' & 13 & *kətug & 'hard (substance)' & 187 \\
\hline *gəуәt & 'penis' & 94 & *k[iə]dəp & 'forehead' & 184 \\
\hline *gilay(-an) & 'man, male' & 75 & *kin(-an) & 'vagina' & 146 \\
\hline *ginan & 'depart, run' & 167 & *kubuy & 'mosquito' & $150^{47}$ \\
\hline *gupad & 'old (woman)' & 195 & *kuduR & 'true' & 124 \\
\hline *gurugud & 'run' & 80 & *kurut & 'summit' & 21 \\
\hline *gutuk & 'run' & 66 & *kuyəy & 'rat' & 2 \\
\hline *haya & 'big' & 194 & *la?u & 'river, water' & 170 \\
\hline *hayin & 'leaf' & 154 & *lab[ia]t & 'tree, wood' & 123 \\
\hline (ma-)*huna & 'girl, woman' & 197 & *laba & 'bury, inter' & 104 \\
\hline *ian & 'fruit' & 88 & *lagum & 'hunt' & 45 \\
\hline *ibəy & 'ear’ & 73 & *lakup & ‘sky’ & 205 \\
\hline *idəm & 'sleep' & 82 & *lambuy & 'tail' & 121 \\
\hline *igay & 'stone' & 156 & *lanis & 'sweet' & 192 \\
\hline *igbər & 'fly (v.)' & 166 & *layad & ‘sit' & 119 \\
\hline *ikag & 'hunt' & 134 & *[1] ayas & 'forehead' & 20 \\
\hline *iknud & 'sit' & 162 & *layg $[i, a] s$ & 'sand' & 141 \\
\hline *ilan & 'accompany' & 34 & *lapsay & 'white' & 148 \\
\hline
\end{tabular}

$47 \quad$ See footnote 33. 


\begin{tabular}{|c|c|c|c|c|c|}
\hline *lapul & ‘dog, puppy’ & 14 & *yuk & ‘call' & 85 \\
\hline *lati & 'rattan' & 1 & *yusu & 'lime' & 74 \\
\hline (ma-)*lawak & 'butterfly' & 105 & *pa?ita & 'choose, say, tell' & 178 \\
\hline *lawi[g] & ‘see’ & 28 & *pagpag & 'fall (v.)' & 111 \\
\hline *lə[?k]aw & 'long' & 93 & *pamalak & 'sun' & 48 \\
\hline *ləbut & 'boil (v.)' & 17 & *paripari & 'fast' & 24 \\
\hline *ligid & 'old (obj.)’ & 47 & *pasa & 'boil (n.)' & 213 \\
\hline *liksap & 'forget' & 18 & *patud & 'man, male' & 27 \\
\hline *lilli & 'butterfly' & 42 & *payun & 'stand' & 98 \\
\hline *limlim & 'butterfly’ & 59 & *pələk & 'thirst' & 8 \\
\hline *linug & 'dizzy, drunk' & 185 & *pənay & 'fever, hot' & 199 \\
\hline *lipa & 'sit' & 142 & *pəsal & 'locust' & 92 \\
\hline$*$ li $[\mathrm{t}]$ lit & 'betel leaf' & 32 & *piad & 'stand' & 120 \\
\hline *lit[əu]b & 'black' & 101 & *pida & ‘sleep’ & 143 \\
\hline *litid & ‘vein' & 4 & *pippun & 'butterfly' & 71 \\
\hline$* 1 \mathrm{u}$ & 'fingernail' & 51 & *pirit & 'short (obj.)' & 181 \\
\hline *lubat & 'sleep’ & 152 & (i-)*plan & 'vagina' & 125 \\
\hline *ludəg & 'mud' & 204 & *pu[?k]na & 'hit, strike' & 90 \\
\hline *[1] udis & 'fingernail' & 51 & ${ }^{*} \mathrm{pu}[\mathrm{st}] \mathrm{ian}$ & 'star' & 201 \\
\hline *lukit & 'mud' & 206 & *puləd & ‘sleep’ & 38 \\
\hline *lukuy & 'ladle' & 135 & *pulug & 'feather, hair' & 16 \\
\hline *lullu & 'butterfly' & 42 & *pun[st]it & 'white' & 203 \\
\hline *lumlum & 'butterfly' & 59 & *punəd & 'rain' & 79 \\
\hline *lunu & 'fingernail' & 113 & *purab & 'hunt' & 9 \\
\hline$*[1]$ usip & 'fingernail' & 11 & *putput & 'feather' & 132 \\
\hline (ma-)*lutəp & 'afternoon' & 68 & *rasa & 'skinny' & 171 \\
\hline *lutit & 'mud' & 191 & *rugus & 'wind' & 157 \\
\hline *luy & 'long (time)' & 136 & *Rəbi & ‘kind, pity’ & 6 \\
\hline *mud[ia]t & 'face' & 182 & *sabit & ‘vagina' & 211 \\
\hline *mugmug(-an) & 'shoulder' & 151 & *sagbun & ‘wall' & 29 \\
\hline
\end{tabular}




\begin{tabular}{|c|c|c|c|c|c|}
\hline *sagnit & 'bone' & 70 & *tanud & ‘wait' & 99 \\
\hline *salad & 'deep, under' & 165 & *tapək & 'earth, soil' & 190 \\
\hline *sanig & 'hear' & 64 & *tapuk & 'rain' & 139 \\
\hline *sayay & 'three' & 122 & *tapuR & 'bury, inter' & 5 \\
\hline *sapuk & 'hair' & 133 & *təkak & ‘bitter’ & 41 \\
\hline *sarik & 'termite' & 49 & *təlip & 'two' & 83 \\
\hline *sarun & 'dry in sun' & 43 & *təmuk & 'burn' & 84 \\
\hline *səlay & 'chin, jaw’ & 160 & *təwali & 'long (time)' & 115 \\
\hline *səlub & 'fragrant' & 22 & *tibəy & 'hear' & 89 \\
\hline *səna & 'sit' & 155 & *tiduk & 'burn' & 103 \\
\hline *sənad & 'waterfall' & 55 & $*$ tim & 'drink' & 72 \\
\hline *səpay & 'back' & 168 & $* \operatorname{tima}[\mathrm{n}, \mathrm{y}]$ & 'hear' & 44 \\
\hline *siak & ‘cry' & 189 & *timuy & 'buttocks' & 106 \\
\hline *sibay & 'dry in sun' & 214 & *tug & 'ladle' & 207 \\
\hline *silit & 'red' & 96 & *tugbak & 'throw, throw away' & 50 \\
\hline$(\mathrm{pa}-)^{*}$ sinil & 'cheek, face' & 169 & *tugkuk & 'sit' & 60 \\
\hline *sipan & 'one' & 78 & *tuyud & 'pregnant' & 37 \\
\hline *sitəb & 'urine' & 62 & *ubun & 'child' & 153 \\
\hline *subuy(-an) & 'shoulder' & 30 & $*[$ uə]di & 'stand' & 144 \\
\hline *sugbuy & 'shoulder' & $30^{48}$ & *uduy(-an) & ‘carabao' & 108 \\
\hline *sugut & ‘walk’ & 63 & *ulay & 'call' & 129 \\
\hline *sula & 'buttocks' & 23 & *urat & 'river, water' & 147 \\
\hline$*$ tabi & 'waterfall' & 196 & *uRdin & 'person, non-Neg.' & 186 \\
\hline *ta[ly]tay & 'summit' & 19 & *uswa & 'blow (v.)' & 102 \\
\hline *tanaw & ‘deep’ & 110 & *wagət & 'river, water' & 188 \\
\hline
\end{tabular}

$48 \quad$ See footnote 17. 


\section{References}

Blust, Robert. 1981. Linguistic evidence for some early Austronesian taboos. American Anthropologist 83:235-319.

Blust, Robert. 1988. Austronesian root theory: An essay on the limits of morphology. Amsterdam/Philadelphia: John Benjamins Publishing Company.

Charles, Mathew. 1973. Charles 72.11 additions not yet in list or English file. Typescript prepared by R. David Zorc, Cornell University. 25pp.

Cooper, John M. 1941. Temporal sequence and the marginal cultures. Anthropological Series, no. 10. Washington, D.C.: Catholic University of America.

Headland, Thomas N., and Janet D. Headland. 1974. A Dumagat (Casiguran)-English dictionary. Pacific Linguistics C-28. Canberra: The Australian National University. Headland, Thomas N., and Alan Healey. 1974. Grammatical sketch of Dumagat (Casiguran), 1-54. Pacific Linguistics A-43. Canberra: The Australian National University.

Headland, Thomas N., and Lawrence A. Reid. 1989. Prehistoric hunter-gatherers and their relationships with agriculturalists. Current Anthropology 30(1):43-51.

Headland, Thomas N., and Lawrence A. Reid. 1991. Holocene foragers and interethnic trade: A critique of the myth of isolated hunter-gatherers. In Between bands and states: Sedentism, subsistence, and interaction in small-scale societies, ed. by Susan A. Gregg, 333-340. Center for Archaeological Investigations, Occasional Paper No. 9. Carbondale: Southern Illinois University Press.

Headland, Thomas N., and Elmer Wolfenden. 1967. The vowels of Casiguran Dumagat. In Studies in Philippine anthropology, ed. by Mario D. Zamora, 592-596. Quezon City: Alemar.

Lambrecht, Frans Hubert, CICM. 1978. Ifugaw-English dictionary. Baguio City: The Catholic Vicar Apostolic of the Mountain Province, Philippines.

Meacham, William. 1991. Further considerations of the hypothesized Austronesian Neolithic migration from South China to Taiwan and Luzon. In Indo-Pacific Prehistory 1990, Volume 2, Proceedings of the $14^{\text {th }}$ Congress, Yogyakarta, editorial coordination by Peter Bellwood, 398-407. Bulletin of the Indo-Pacific Prehistory Association 11. Canberra: Indo-Pacific Prehistory Association.

Panganiban, José Villa. 1972. Diksyunaryo tesauro Pilipino-Ingles. Quezon City: Manlapaz Publishing Co. 
Pennoyer, F. Douglas. 1986-87. Inati: The hidden Negrito language of Panay, Philippines. Philippine Journal of Linguistics 17(2) -18(1):1-37.

Reid, Lawrence A., ed. 1971. Philippine minor languages: Word lists and phonologies. Oceanic Linguistics Special Publication No. 8. Honolulu: University of Hawai'i Press.

Reid, Lawrence A. 1973. Diachronic typology of Philippine vowel systems. In Current trends in linguistics, vol. 11, ed. by Thomas A. Sebeok, 485-506. The Hague: Mouton.

Reid, Lawrence A. 1987. The early switch hypothesis: Linguistic evidence for contact between Negritos and Austronesians. Man and Culture in Oceania 3 (Special Issue):41-59.

Reid, Lawrence A. 1989a. Arta, another Philippine Negrito language. Oceanic Linguistics 28:47-74.

Reid, Lawrence A. 1989b. Unraveling the linguistic prehistories of Philippine Negritos. Paper presented to the Conference on Contact Induced Change in Austronesian Languages, Australian National University, Canberra. [Published in 1994 in Language contact and change in the Austronesian world, ed. by Tom Dutton and Darrell T. Tryon, 443-475. Berlin: Mouton de Gruyter.]

Reid, Lawrence A. 1990. Fieldnotes (Arta, Northern and Southern Alta, and Central Agta).

Reid, Lawrence A. 1991. The Alta languages of the Philippines. In Papers from the Fifth International Conference on Austronesian Linguistics, VICAL 2, Western Austronesian and contact languages, ed. by Ray Harlow, 265-297. Auckland: Linguistic Society of New Zealand.

Santos, Pilar C. 1975. Sinauna Tagalog: A genetic study examining its relationship with other Philippine languages. M.A. thesis, Ateneo de Manila University, Quezon City. Wimbish, John. 1986. The languages of the Zambales mountains: A Philippine lexicostatistic study. In Work Papers of the Summer Institute of Linguistics, University of North Dakota Session, vol. 30:133-142.

Yap, Fe Aldave. 1977. A comparative study of Philippine lexicons. Manila: Institute of National Language. 